\title{
Controlling Action Times in Daily Workforce Schedules
}

\author{
Gary M. Thompson
}

\begin{abstract}
Action times occur when a shift or break starts or finishes. It is found that the number of action times can be reduced or increased substantially without increasing the amount of unproductive staffing. Reducing the number of action times reduces the managerial burden of schedule implementation, while increasing the number of action times allows for more effective real-time schedule control.
\end{abstract}

This article introduces the concept of action times in workforce shift scheduling. An action time is a time at which the status of the schedule changes; that is, when a shift or break starts or finishes. The article examines the number of action times in workforce schedules under an extensive set of shiftscheduling scenarios. Using two new formulations of the workforce shift-scheduling problem (WSSP), it is found that the number of action times can be reduced by approximately $16 \%$ or increased by approximately $18 \%$. Neither the reduction nor the increase in the number of action times requires an increase in the amount of surplus, unproductive stafing compared to schedules generated with a traditional formulation of the WSSP. These results should be of interest to hospitality managers for two reasons. First, reducing the number of action times reduces the managerial burden of schedule implementation in environments having stable customer demand. Second, increasing the number of action times allows for more effective real-time control in environments having unstable customer demand. Effective real-time control ensures that the appropriate level of customer service is provided economically.

IN THIS ARTICLE I FOCUS on hospitality service systems that exhibit within-day variation in customer demand. Because the consumption of the service occurs simultaneously with its delivery, excess capacity often cannot be put to productive use. Managers of such hospitality service functions are thus faced with the task of providing just enough capacity to provide the level of service customers expect. When the unit of capacity is

Gary M. Thompson is Associate Professor of Operations Management, School of Hotel Administration, Cornell University, Ithaca, NX 14853 607-255-8214 (Office), 607-255-4179 (Fax), Intemet: GMT1@CORNELL.EDU. labor, this managerial task is known as workforce scheduling.

Customer demand that varies over an operating day complicates workforce scheduling in several important ways. First, managers typically determine their staffing needs using time periods, or planning intervals, that are substantially shorter than the length of the operating day (Agnihothri \& Taylor, 1991; Andrews \& Parsons, 1989; Holloran \& Byrn, 1986; Love \& Hoey, 1990; Schindler \& Semmel, 1993). In general, shorter planning intervals are preferable with higher within-day variation in customer demand. Also, in attempting to provide just enough labor capacity, managers often resort to using shifts ${ }^{1}$ that vary in length and that overlap. Although using overlapping shifts that vary in length enables a closer match of capacity to demand, the demands on a manager increase because there are more action times. Action times occur when the workforce status changes and include the starting and finishing of shifts and breaks.

The degree of stability of customer demand influences managers' aims with regard to the number of action times in the workforce schedule. In environments with relatively stable customer demand (i.e., there is little difference between the forecast and actual customer demand), managers want the workforce schedule to be implemented as planned. Thus, they may wish to minimize the number of action times be-

\footnotetext{
${ }^{2}$ For our purposes, shifts are composed of an initial work stretch (covering multiple planning intervals), an unpaid meal break (which may cover a single or several planning intervals), and a second work stretch (also covering several planning intervals).
} 
cause this reduces the times at which supervision is needed to ensure consistency between the actual and scheduled changes in workforce status. By contrast, in environments with relatively unstable demand (i.e., there is a measurable difference between the forecast and actual customer demand), managers need to make frequent changes to the workforce schedule in real-time to ensure the delivery of a high level of customer service. Hospitality managers using part-time employees have a wide range of real-time schedule control mechanisms at their disposal. If customer demand is higher than anticipated they can call additional employees in to work, send employees home later than planned, defer employees' breaks, or recall employees from breaks. Similarly, if customer demand is lighter than anticipated, they can call off employees, send employees home earlier than planned, or send employees on early breaks. Thus, in unstable environments, hospitality managers should strive to have workforce schedules with many action times, since the greater dispersion of action times facilitates effective real-time schedule changes. For example, consider two scenarios, one where all the scheduled shifts either finish at 4:00 or 5:00 p.m., and another where the shift finishes are spread across the times of 4:00, 4:15, 4:30, 4:45, and 5:00 p.m. Clearly, the former requires less supervision to implement, but it also offers less flexibility in extending the length of shifts should demand turn out to be higher than anticipated between 4:15 and 5:00 p.m., since there are no employees finishing work between 4:00 and 5:00 whose shifts can be extended.

In this article, we present an analysis of action times in workforce scheduling, the first to our knowledge. Specifically, we wish to see if a manager may reduce the number of action times, and thus reduce the managerial burden of implementing a schedule (in stable environments). We also wish to see if a manager might increase the number of action times, thus obtaining a schedule more suited to environments with unstable demand. Ideally, one would like to accomplish these objectives without increasing the cost of the workforce schedule and without unduly affecting the employees. To accomplish our objectives, we introduce two new formulations of the workforce shift-scheduling problem (WSSP) that explicitly account for action times.

We begin by examining the degree of control over action times that is possible in a typical fast-food establishment. We also conduct a broad experiment over a set of WSSPs designed to mimic those that occur in a wide range of hospitality service functions. Specifically, we vary the length of planning intervals, the length of the operating day, the number of daily peaks in the employee requirements, the variation in the employee requirements over the operating day, the mean employee requirements, and the degree of scheduling flexibility to develop a set of 972 scheduling scenarios. These factors enable us to investigate a managerial question such as, What happens to the number of action times as one shortens the duration of planning intervals, reduces the variability of customer demand through demand modification activities, or increases the level of scheduling flexibility?

The structure of the remainder of this article is as follows. The next section presents a brief overview of the traditional and our new mathematical-programming formulations of the WSSP. The following section illustrates the degree of control over action times that is possible in a typical fast-food establishment. Subsequent sections then address the design of our large experiment, present and discuss the results of this experiment, and offer concluding remarks. Appendix A presents the traditional and our new mathematical models of the WSSP. Appendices B through D present optimal shift schedules for an example fast-food restaurant, which illustrate the control of action times that is possible.

\section{Workforce Shift Scheduling Formulations}

Dantzig (1954) provided the basic mathematical-programming formulation of the WSSP, a model we call F1. F1 has the objective of minimizing the cost of the workforce schedule. Several researchers, most recently Easton and Rossin (1991), have noted the existence of multiple optimal solutions to workforce scheduling problems having a single objective, making it worthwhile to incorporate a secondary objective in a WSSP. Our first new formulation of the WSSP, F2, is a preemptive-programming formulation (PPF) with two objective components. F2's primary objective of minimizing the cost of the schedule is identical to F1's objective. F2's secondary objective is to minimize the number of action times, which, as noted earlier, is useful in reducing the managerial demands of implementing schedules in environments with stable customer demand.

Our second new formulation of the WSSP, F3, is also a PPF, and is similar to F2 except that F3's secondary objective maximizes the number of action times. As we noted in the introduction, having more action times increases the managerial burden of implementing a schedule, but offers a higher degree of flexibility in modifying the schedule in real-time to respond to unpredictable variability in customer demand. Appendix A presents the mathematical forms of F1, F2, and F3.

$\mathrm{F} 1$ and its variants have been widely used in the WSSP literature (most recently by Easton \& Rossin, 1991; Love \& Hoey, 1990; Schindler \& Semmel, 
1993). We thus consider workforce schedules developed using F1 to be "traditional." In both our fast-food example and our broad experiment, we compare F1's traditional schedules to those developed using our new models of the WSSP. This enables us to investigate the degree of control that is possible over action times when using our new models.

\section{An Example Of Action Time Control}

Figure 1 illustrates forecast employee requirements by 15-minute intervals for a weekday at a fast-food establishment open from 6:00 a.m. to 2:00 a.m. (20 hours). A total of 575 employee-periods of work (143.75 labor hours) are necessary to satisfy forecast customer demand. Allowable shifts are six through 11 hours, including an hour-long break that must be preceded and followed by at least one, but no more than six, hours of work.

Appendix B presents the optimal shift schedule for the problem obtained using the traditional formulation, F1. This schedule has 22 employees working a total of 144 labor hours, which is a surplus of 0.25 labor hours over the ideal level. It also has 46 action times. Appendix $C$ presents the optimal shift schedule to the problem obtained using our new model that attempts to minimize the number of action times as a secondary objective (F2). This schedule also contains 22 employees working a total of 144 labor hours, but the number of action times is reduced to 39 , a $15.2 \%$ reduction compared to the traditional schedule. An example of the reduction in action times may be seen in comparing the breaks of shifts $19-22$ in both schedules. The traditional schedule of F1 splits the four breaks into two groups over a two-hour period, while F2 has scheduled them simultaneously. A reduction in action times thus simplifies the managerial task of ensuring that schedule changes happen at the specified times.

Appendix D presents the optimal shift schedule to the problem developed using F3, our new model that attempts to maximize the number of action times as a secondary objective. This schedule contains 24 employees working the same total (144) labor hours scheduled by F1 and F2. However, the number of action times has increased to 56 , a $21.7 \%$ increase compared to the traditional schedule. An example of the increase in action times that F3 offers can be seen by comparing the schedules in Appendices B and D. Specifically, the traditional schedule in Appendix B shows three shifts finishing at 7:30 p.m. and another three finishing at 10:30 p.m. Note, however, that F3's schedule distributes

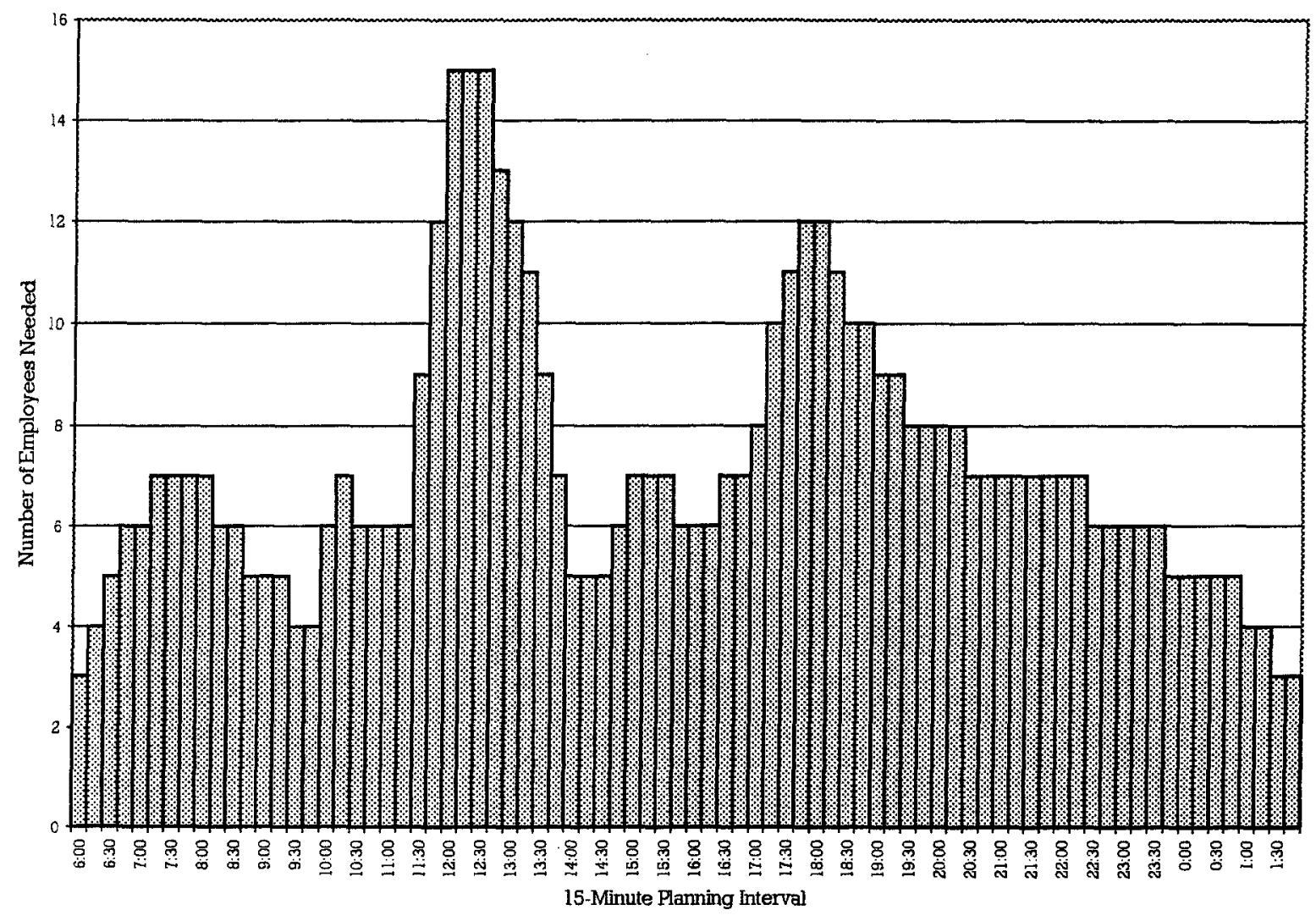

FIGURE 1. Employee requirements in the sample fast-food establishment. 
these shift finishes over several periods. This supports our contention that real-time control will be more effective with schedules having more action times. F3's schedule offers a higher degree of flexibility in responding to higher- or lower-than-expected levels of demand than does the traditional schedule of F1.

In the next sections we describe our efforts to evaluate the ability of our new models to control action. times in a much wider variety of hospitality service delivery environments. As we will see, the results from the preceding example are very consistent with those observed over a broad range of conditions.

\section{Experimental Issues}

This section has two aims. First, it describes the design of the experiment investigating action times. Second, it describes the procedures we followed in generating schedules using F1, F2, and F3.

\section{Experimental Design}

To investigate the number and distribution of action times, and whether it is possible to reduce or increase the number of action times, we developed a set of 972 WSSP. These problems vary on six characteristics, as Table 1 reports.

The first WSSP characteristic is the length of planning intervals. We used planning interval lengths commonly used in practice: 60 minutes, 30 minutes, and 15 minutes. The second WSSP characteristic is the length of the operating day. We selected operating days of 12 , 16 , and 20 hours, representing a range of operating hours existing in service functions.

The employee requirements, the third WSSP characteristic, were one of four shapes, based on the number of peaks in the requirements during the day; examples are shown in Figure 2. In reality, the shape of the requirements depends on when customer demand occurs. In turn, the nature of the service determines when cus-

TABLE 1. Characteristics of the test problems

\begin{tabular}{|c|c|}
\hline Problem characteristic & $\begin{array}{l}\text { Values of the problem } \\
\text { characteristic }\end{array}$ \\
\hline $\begin{array}{l}\text { Planning interval duration } \\
\text { (minutes) }\end{array}$ & 60,30, and 15 \\
\hline $\begin{array}{l}\text { Operating day length } \\
\text { (hours) }\end{array}$ & 12,16 , and 20 \\
\hline $\begin{array}{l}\text { Number of peaks in the } \\
\text { employee requirements }\end{array}$ & $1,2,3$, many \\
\hline $\begin{array}{l}\text { Variation in the employee } \\
\text { requirements }\end{array}$ & $\begin{array}{l}\text { Coefficient of variations } \\
\text { of approximately } 0.15 \text {, } \\
0.30 \text {, and } 0.60\end{array}$ \\
\hline $\begin{array}{l}\text { Mean employee } \\
\text { requirements }\end{array}$ & 5,15, and 45 \\
\hline Scheduling flexibility & Low, medium, and high \\
\hline
\end{tabular}

tomer demand occurs. Examples of one and two daily peaks are weekend demand for services at a ski resort and the front desk operations at hotels, respectively. Three daily peaks in requirements occur commonly in restaurants. Requirements with many daily peaks occur in hospitality organizations where customer demand has various determinants; for example, in telephone reservations centers that serve customers in several time zones. The patterns illustrated in Figure 2 are meant to be broadly representative of the type of customer demand patterns that can occur in hospitality organizations. Although a particular hospitality business may not exhibit a pattern precisely like any of those we used, using a range of patterns helps ensure the broad applicability of our results.

The fourth WSSP characteristic is the variation in the employee requirements over the operating day. We selected three levels of variation, measured using the coefficient of variation of the requirements over the operating day. Such a measure is useful in measuring the amount of variation relative to the mean requirements. The three coefficients of variation are 0.15 , 0.30 , and 0.60 . In general, greater within-day variation in customer demand (and thus greater variation in the employee requirements) increases the difficulty of matching scheduled labor capacity to needed labor capacity. Consequently, managers often attempt to smooth the peaks and valleys of customer demand through demand modification activities. The levels of variation of employee requirements allow us to examine the effects of such demand modification activities.

We generated the requirements using three mean requirement levels, 5, 15, and 45 employees, the fifth WSSP characteristic. We selected this characteristic to examine whether higher mean requirements require more or fewer action times, in general. The low, medium, and high levels of mean requirements may be seen in small fast-food establishments, airline check-in counters at large airports, and moderately sized telephone reservation centers, for example.

The combinations of planning interval duration, operating day length, peaks in the employee requirements, variation in the employee requirements, and mean employee requirements yielded 324 distinct employee requirements patterns. Figure 2 illustrates the eight patterns with 15-minute planning intervals, a 16-hour operating day, low and high variation in the employee requirements, and mean requirements of 15 employees.

The final characteristic of the WSSPs is the degree of scheduling flexibility, a characteristic that measures the range of alternative shifts that one can draw upon when developing a labor schedule. At the low level of scheduling flexibility, shifts are eight to nine hours, including 


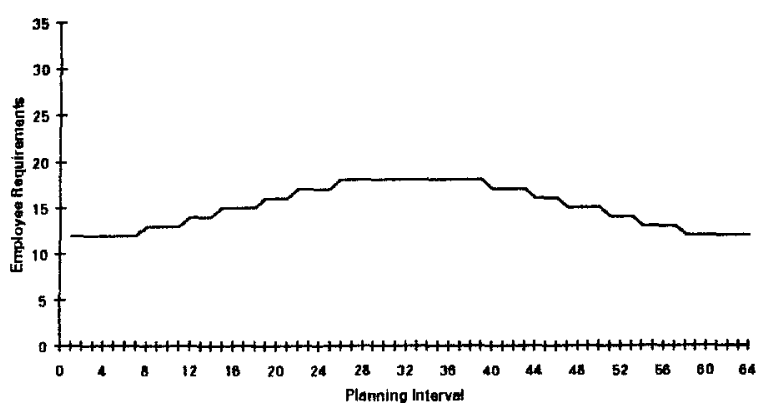

(a)

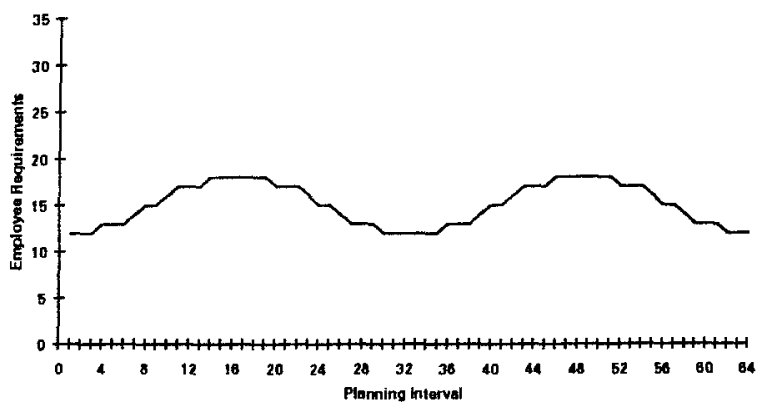

(c)

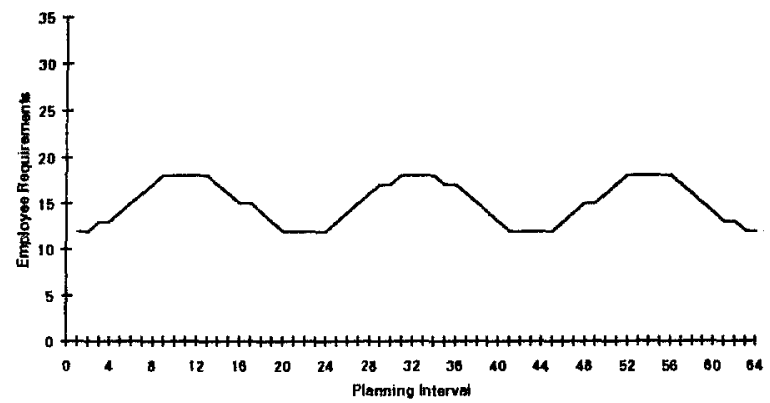

(e)

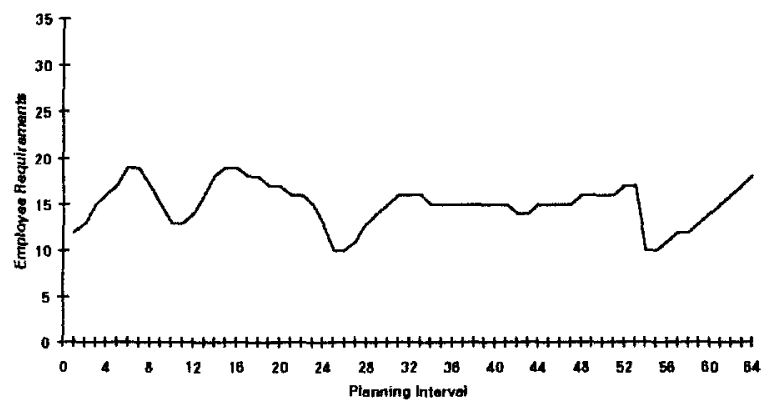

(g)

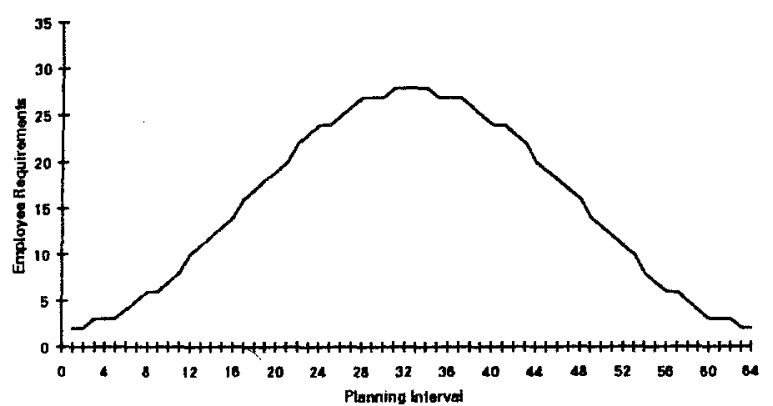

(b)

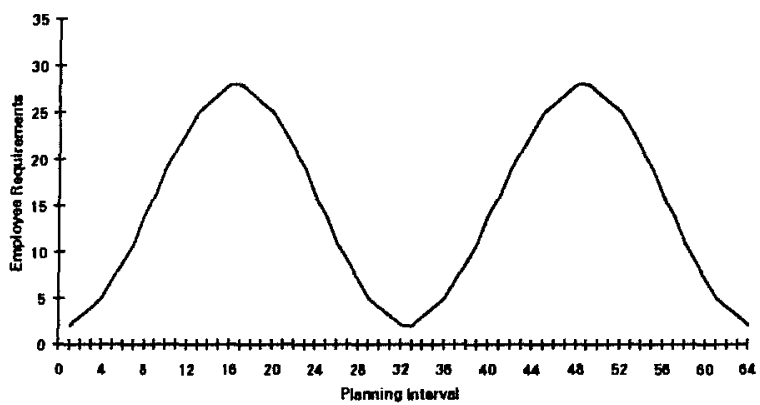

(d)

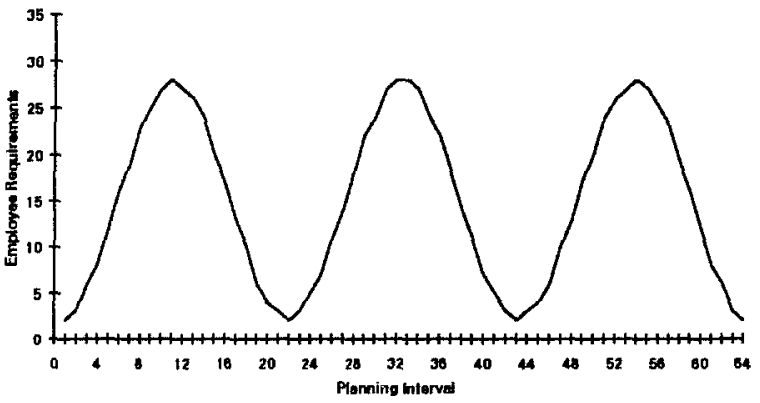

(f)

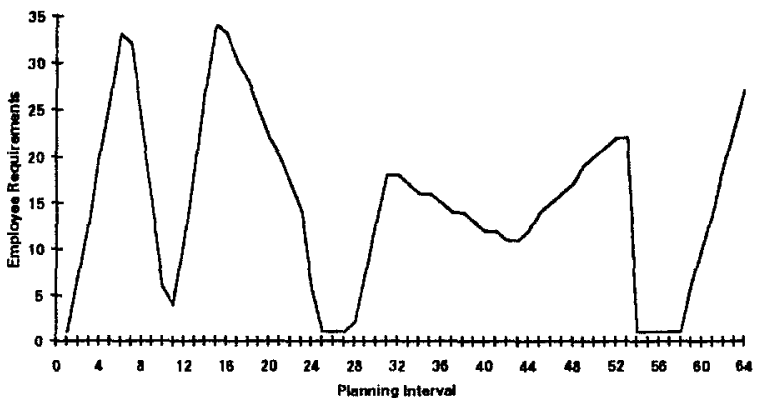

(h)

FIGURE 2. The eight employee requirements patterns with 15 -minute planning intervals, a 16-hour operating day, and mean requirements of 15 employees ((a) low- and (b) high-variation one-daily-requirement-peak patterns; (c) low- and (d) high-variation two-daily-re quirement-peak patterns; (e) low- and (A) high-variation three-daily-requirement-peak patterns; and (g) low-and (h) high-variation manydaily-requirement-peak patterns). 
an hour-long break that must be preceded and followed by at least three, but no more than four, hours of work. At the medium level of scheduling flexibility, shifts are seven through 10 hours, including an hourlong break that must be preceded and followed by at least two, but no more than five, hours of work. At the high level of scheduling flexibility, shifts are six through 11 hours, including an hour-long break that must be preceded and followed by at least one, but no more than six, hours of work. Shift lengths and the duration of pre- and post-break work stretches vary in increments of the planning interval duration. For example, with 15-minute planning intervals under the high level of scheduling flexibility, acceptable shift lengths are 6 , $6.25,6.5, \ldots, 10.75$, and 11 hours. Table 2 shows the number of different shifts that can be scheduled under the three flexibility levels, by level of planning interval duration and operating day length. The number of shifts ranges from 14 in the WSSPs with 60-minute planning intervals, 12-hour operating days, and low scheduling flexibility - to 15,587 in the WSSPs with 15-minute planning intervals, 20-hour operating days, and high scheduling flexibility. In a previous study Thompson (1995) found that higher scheduling flexibility reduced the amount of surplus, unproductive labor in a workforce schedule. Increasing the level of scheduling flexibility combinatorially complicates the development of the workforce schedule, however.

\section{Solving F1, F2, and F3}

We solved F1 using commercially available MixedInteger-Programming (MIP) software, and used a twostep approach to solve F2 and F3 using the same software. F2A (F3A), the first MIP formulation of F2 (F3), minimized only the primary objective component of F2 (F3). F2B (F3B), the second MIP formulation, mini-

TABLE 2. Number of alternate shifts, by level of relevant WSSP characteristic

\begin{tabular}{ccccr}
\hline $\begin{array}{c}\text { Planning } \\
\text { interval } \\
\text { duration } \\
\text { (minutes) }\end{array}$ & $\begin{array}{c}\text { Operating day } \\
\text { length (hours) }\end{array}$ & \multicolumn{3}{c}{$\begin{array}{c}\text { Degree of scheduling } \\
\text { flexibility }\end{array}$} \\
\hline \multirow{2}{*}{60} & 12 & 14 & 56 & 126 \\
& 16 & 26 & 104 & 234 \\
& 20 & 38 & 152 & 342 \\
& 12 & 50 & 300 & 750 \\
30 & 16 & 98 & 588 & 1,470 \\
& 20 & 146 & 876 & 2,190 \\
& & & & \\
& 12 & 235 & 1,927 & 5,123 \\
15 & 16 & 475 & 3,895 & 10,355 \\
& 20 & 715 & 5,863 & 15,587 \\
\hline
\end{tabular}

mized the secondary objective component of F2 (F3), while constraining the primary objective component to equal the best value found when solving $\mathrm{F} 2 \mathrm{~A}(\mathrm{~F} 3 \mathrm{~A})$. Since F2A (F3A) is identical to F1, the first step in solving F2 (F3) was to find the least costly schedule; the second step then found a schedule of the same cost that had the fewest (greatest) number of action times.

For F1 and both forms of F2 and F3, we used the implicit formulation of Thompson (1995) to represent shifts (constraint set (2) from Appendix A). An implicit formulation greatly reduces the number of variables needed to represent the large number of shifts in labor scheduling problems. By using an implicit representation of shifts, for example, we were able to represent the 15,587 shifts in some of our WSSPs using only 184 variables. We used GAMS (Brooke et al., 1992) to generate each formulation and OSL (IBM Corporation, 1991) to solve the formulations ${ }^{2}$. We also imposed a three-, six-, or nine-minute time limit on the solution of each implementation of F1, F2, and F3, depending on the length of planning intervals (longer times with shorter planning intervals). If OSL did not solve the formulation optimally within the available time, we used the best integer solution found. Of the 972 WSSPs, F1, F2, and F3, respectively, failed to solve 1, 150 , and 54 of the WSSPs to optimality within the imposed time limits.

\section{Experimental Results}

Solving F1, F2, and F3, respectively, required 11.33, 52.60 , and 29.98 seconds, on average, on a Pentium 100-based personal computer with 48 megabytes of RAM. Thus, solving F2, with its secondary objective of minimizing the number of action times, was more difficult than solving F3, with its secondary objective of maximizing the number of action times. As expected, increasing the number of planning intervals (by reducing the length of the planning intervals) increased the solution times for all formulations. For example, F3 required $7.60,15.64$, and 66.70 seconds to solve with $60-, 30-$, and 15-minute planning periods, respectively.

Table 3 presents a summary of action time results by level of the experimental factors. Overall, F2's (F3's) schedules used $15.8 \%$ fewer $(18.1 \%$ more) action times than did F1's schedules, results that are very consistent with those from our earlier example. The number of action times in F2's schedules decreased when measured

\footnotetext{
${ }^{2}$ With OSL, we used the parameters OPTCR $=0.0$, OPTCA $=999$. This allows OSL to terminate when it has found an integer solution with an objective no more than 0.999 greater than the current lower bound on the best integer solution. Given the integer-valued objectives, such a solution must be optimal.
} 
TABLE 3. Summary of action time results, by level of the experimental factors ${ }^{1}$

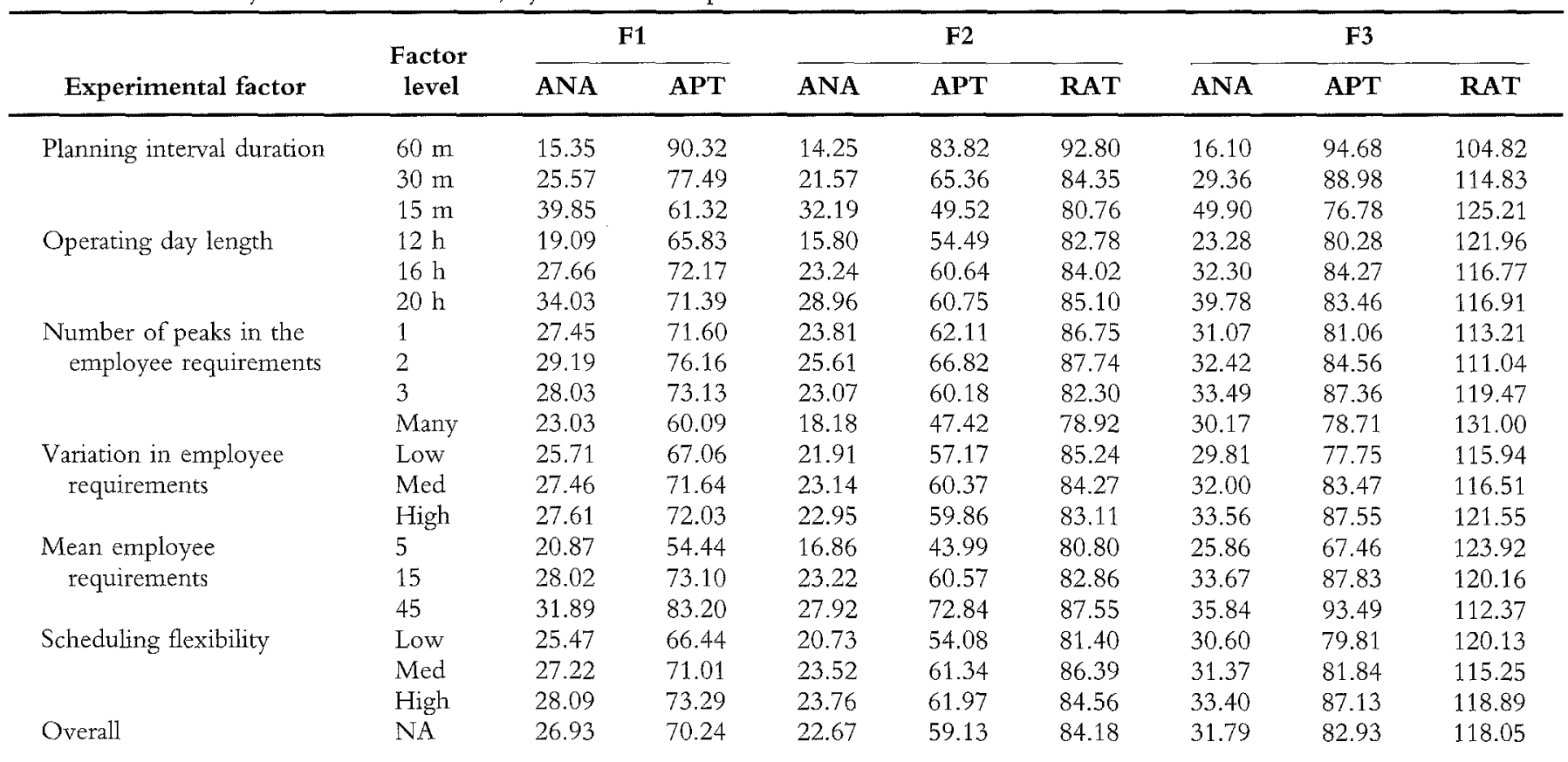

${ }^{1} \mathrm{ANA}=$ average number of action times; APT $=$ average number of action times as a percentage of the total possible number of action times; and $\mathrm{RAT}=$ the average number of action times for F2 (or F3) expressed as a percentage of the average number of action times for F1.

as a percentage of the number of action times in F1's schedules, with shorter planning intervals, longer operating days, higher variation in the employee requirements, and lower mean employee requirements. Very similarly, the number of action times in F3's schedules increased when measured as a percentage of the number of action times in F1's schedules, with shorter planning intervals, higher variation in the employee requirements, and lower mean employee requirements.

Table 4 presents, by level of the experimental factors, a summary of scheduled labor hours and number of shifts scheduled by F1, F2, and F3. On average, F1, F2, and F3 scheduled 411.2 labor hours, representing average excess staffing of $18.6 \%$. Overall, F2 (F3) scheduled $1.2 \%(0.7 \%)$ more shifts than F1. These results show there was little difference in the number of shifts scheduled by the competing formulations, which implies that the shift durations were also very similar across the formulations' schedules. These results are important in that they demonstrate that employees will not bear any appreciable burden - either by working longer or shorter shifts than normal- of the increased or decreased number of action times.

Table 5 presents the results of two ordinary least squares regressions. The dependent variables in these regressions are the percentage reduction and increase in action times that $\mathrm{F} 2$ and $\mathrm{F} 3$ yielded compared to $\mathrm{F} 1$. Independent variables in each regression are: the number of planning intervals per hour $(1,2$, or 4$)$; the length of the operating day in hours $(12,16$, or 20$)$; the mean employee requirements $(5,15$, or 45$)$; the coefficient of variation in the employee requirements $(0.15,0.30$, or 0.60$)$; the number of daily peaks in the employee requirements $(1,2,3$, or 5$)$; and the level of scheduling flexibility $(1,2$, or 3$)$. For the percentage reduction in action times (offered by $\mathrm{F} 2$ compared to $\mathrm{F} 1$ ), the regression model has an $\mathrm{R}^{2}$ of 0.22 . All of the coefficients are significant at the 0.01 level or lower, except the length of operating day, which is significant at the 0.1 level. The coefficients show that a greater percentage reduction in action times is achievable with, in order of declining importance: more planning intervals per hour; more peaks in the employee requirements; lower mean employee requirements; higher variation in the employee requirements; lower scheduling flexibility; and shorter operating days.

For the percentage increase in action times (offered by $\mathrm{F} 3$ compared to $\mathrm{F} 1$ ), the regression model has an $\mathrm{R}^{2}$ of 0.30 . All of the coefficients are significant at the 0.001 level, except the level of scheduling flexibility and the intercept, neither of which is significant at the 0.2 level. The coefficients show that a greater percentage increase in action times is achievable with, in order of declining importance: more planning intervals per hour; more peaks in the employee requirements; lower mean employee requirements; higher variation in the employee requirements; and shorter operating days. 
TABLE 4. Summary of additional results, by level of the experimental factors

\begin{tabular}{|c|c|c|c|c|c|c|c|}
\hline \multirow[b]{3}{*}{ Experimental factor } & \multirow{3}{*}{$\begin{array}{l}\text { Factor } \\
\text { level }\end{array}$} & \multirow{3}{*}{$\begin{array}{c}\text { Average } \\
\text { scheduled } \\
\text { labor } \\
\text { hours }\end{array}$} & \multicolumn{5}{|c|}{ Scheduled shifts ${ }^{1}$} \\
\hline & & & \multirow{2}{*}{$\frac{F 1}{A N S}$} & \multicolumn{2}{|c|}{$\bar{F} 2$} & \multicolumn{2}{|c|}{ F3 } \\
\hline & & & & ANS & RNS & ANS & RNS \\
\hline \multirow[t]{3}{*}{ Planning interval duration } & $60 \mathrm{~m}$ & $407.29^{2}$ & 60.00 & 60.70 & 101.16 & 60.10 & 100.16 \\
\hline & $30 \mathrm{~m}$ & 412.04 & 60.39 & 61.29 & 101.49 & 60.95 & 100.93 \\
\hline & $15 \mathrm{~m}$ & 414.20 & 61.00 & 61.57 & 100.93 & 61.64 & 101.05 \\
\hline Operating day length & $20 \mathrm{~h}$ & 488.10 & 69.71 & 71.17 & 102.09 & 70.60 & 101.28 \\
\hline \multirow{4}{*}{$\begin{array}{l}\text { Number of peaks in the } \\
\text { employee requirements }\end{array}$} & 1 & 352.58 & 48.41 & 50.54 & 104.40 & 49.63 & 102.52 \\
\hline & 2 & 398.18 & 59.22 & 59.29 & 100.12 & 59.51 & 100.49 \\
\hline & 3 & 418.04 & 61.27 & 61.71 & 100.72 & 61.51 & 100.40 \\
\hline & Many & 475.92 & 72.95 & 73.20 & 100.33 & 72.93 & 99.97 \\
\hline $\begin{array}{l}\text { Variation in employee } \\
\text { requirements }\end{array}$ & Low & 375.97 & 54.34 & 55.21 & 101.61 & 54.83 & 100.90 \\
\hline requirements & 45 & 853.02 & 125.32 & 127.06 & 101.39 & 125.84 & 100.41 \\
\hline \multirow[t]{3}{*}{ Scheduling flexibility } & Low & 460.77 & 64.53 & 64.54 & 100.01 & 64.54 & 100.01 \\
\hline & Med & 398.73 & 58.27 & 58.69 & 100.71 & 58.70 & 100.74 \\
\hline & High & 374.04 & 58.59 & 60.33 & 102.97 & 59.45 & 101.46 \\
\hline Overall results & $\mathrm{NA}$ & 411.18 & 60.46 & 61.18 & 101.19 & 60.90 & 100.72 \\
\hline
\end{tabular}

${ }^{1}$ ANS $=$ average number of scheduled shifts; RNS = the average number of shifts scheduled by F2 (or F3) expressed as a percentage of the average number of shifts scheduled by F1.

${ }^{2}$ Scheduled labor hour differs across length of planning intervals because the employee requirements patterns are different across planning interval lengths.

\section{Discussion of the Experimental Results}

\section{Planning Interval Duration}

The number of action times increased for F1, F2, and F3 with shorter-duration planning intervals. With F2, $\mathrm{F} 1$, and F3, actions, respectively, occurred at 83.8 , 90.3 , and $94.7 \%$ of the possible times with 60 -minute planning intervals. These percentages dropped to 49.5 , 67.3 , and 77.5 with 15-minute planning intervals, respectively. As the planning intervals became shorter, F2 (F3) yielded a greater percentage decrease (increase) in the number of action times compared to F1. Thus, in environments with stable customer demand, F2 will enable managers to offset some of the additional schedule implementation effort required by the use of shorter-duration planning intervals. F3's results show that in environments having unstable customer demand, realtime control of its schedules will be more effective under shorter planning intervals than for F1's schedules.

\section{Operating Day Length}

Although the number of action times increased for $\mathrm{F} 1$, F2, and F3 with longer operating days, the length of the operating day seemed not to greatly influence the percentage of possible times at which actions occur. For example, $\mathrm{F} 1$ had actions at $65.8,72.2$, and $71.4 \%$ of the possible times with 12-, 16-, and 20-hour operating days, respectively. The percentage reduction in the number of action times offered by F2 also appeared unrelated to the length of the operating day. These results indicate that F2's usefulness in reducing the managerial burden of schedule implementation is not dependent on a particular length of operating day, at least over the range of daily durations that we considered. Similarly, the value of F3 in increasing the number of action times appears robust across different lengths of the operating day.

Number of Daily Peaks in the Employee Requirements Overstaffing increased with increases in the number of daily peaks in the employee requirements. F2 (F3) enabled a $21 \%$ reduction ( $31 \%$ increase) in the number of action times compared to $\mathrm{F} 1$ when the employee requirements had many daily peaks. This suggests that F2 (F3) will be broadly effective in reducing (increasing) the number of action times in service environments, since irregular employee requirements are common in service organizations.

\section{Variation in the Employee Requirements}

Greater variation in the employee requirements had three effects. First, overstaffing was substantially higher. Second, for F1, F2, and F3 there were generally more action times. Third, F2 (F3) yielded a greater percent- 
TABLE 5. Regression results

SUMMARY OUTPUT for Model 1 having as dependent variable the percentage reduction in action times offered by F2 compared to F1

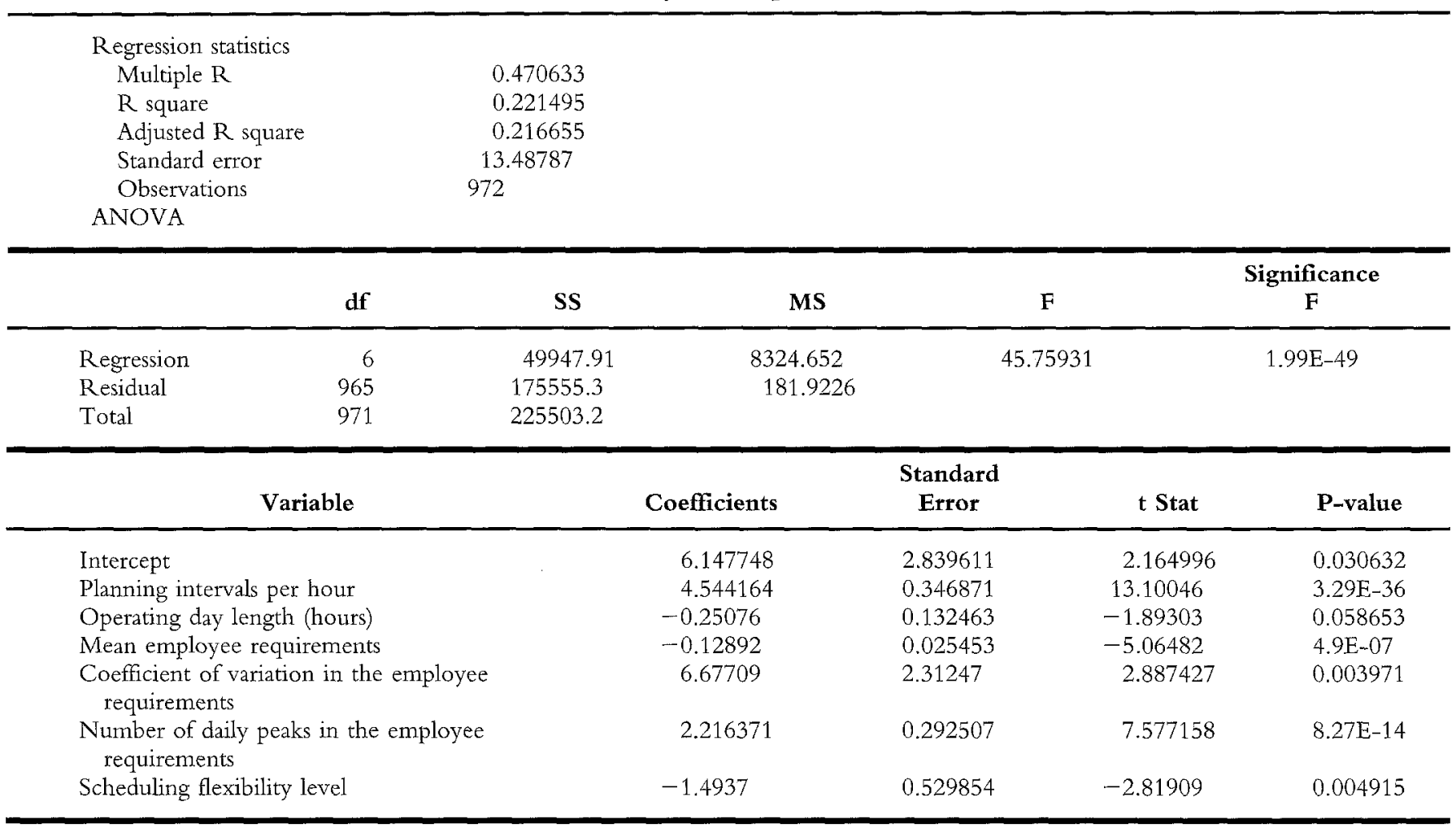

SUMMARY OUTPUT for Model 2 having as dependent variable the percentage increase in action times offered by $\mathrm{F} 3$ compared to $\mathrm{F} 1$

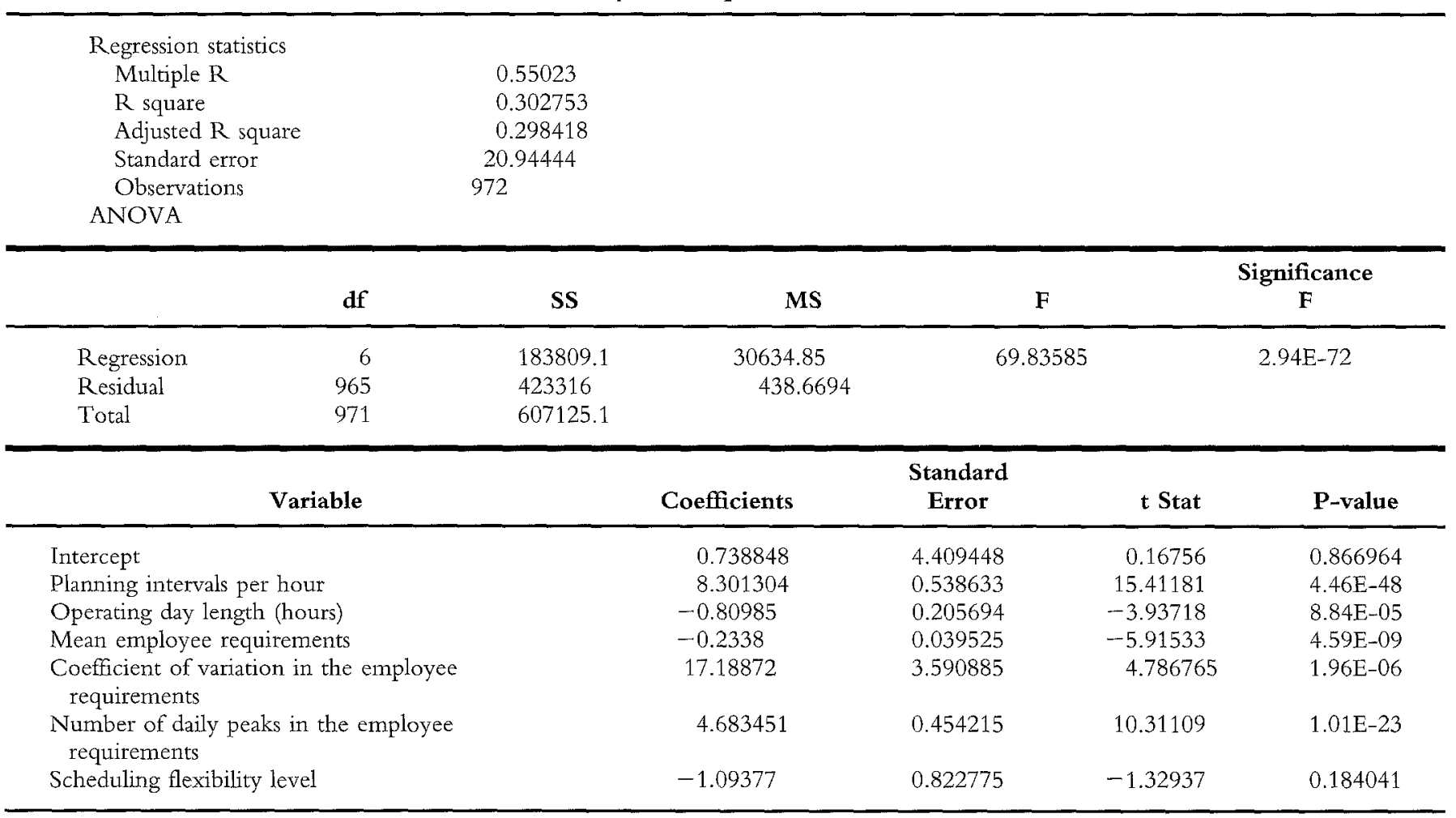


age reduction (increase) in the number of action times compared to F1. Managers often cannot influence the degree of variability in the demand for their service (and hence the variability in the employee requirements). When they can influence this variability, they usually attempt to reduce it. Our results show that F2 (F3) continues to have a substantial ability to reduce (increase) the number of action times even as the variability is reduced: compared to F1, F2 (F3) enabled more than a $14 \%$ reduction ( $15 \%$ increase) in the number of action times under the lowest level of variation in the employee requirements.

\section{Mean Employee Requirements}

First, F2 (F3) used proportionally fewer (more) action times than did F1 with lower mean employee requirements. Second, there was a slight decrease in the percentage overstaffing with higher mean employee requirements. Finally, F1, F2, and F3 all used more action times with higher mean employee requirements. Intuitively, this result makes sense in that the magnitude of staffing changes across planning intervals is larger with higher mean employee requirements (even though we held the relative changes in staffing levels across planning intervals constant across the levels of mean requirements).

\section{Scheduling Flexibility}

As one would expect, increasing the level of scheduling flexibility increased the total number of action times for F1, F2, and F3. Across the levels of scheduling flexibility, F2 (F3) was broadly effective in reducing (increasing) the number of action times compared to F1. The increase in flexibility also resulted in a substantial decrease in the excess staffing levels for all formulations. At the low level of scheduling flexibility, 460.77 labor hours were scheduled on average, compared to the $346.67(=(5+15+45) / 3 \star(12+16+20) / 3)$ hours needed, or a surplus of $32.9 \%$. At the medium level of scheduling flexibility, the surplus hours dropped to $15.0 \%$, and then to $7.9 \%$ at the high level of scheduling flexibility. This finding offers further support for the relationship between flexibility and surplus labor observed by Thompson (1995).

\section{Conclusions}

This article has defined action times and presented the first analysis of these times in WSSPs. It also presented two new formulations of the WSSP that are designed to offer managers control over action times. We see four major conclusions from our work.

First, for schedules generated using a traditional formulation of the WSSP, F1, we have observed increases in the number of action times with shorter planning intervals, longer operating days, higher employee requirements, and greater scheduling flexibility. This shows that as managers move toward the use of shorter-duration planning intervals and higher scheduling flexibility - so that they can better match capacity to demand-their workforce shift schedules will have more action times.

Second, across the 972 WSSPs we examined, our first new formulation, $\mathrm{F} 2$, yielded a $15.8 \%$ reduction in the number of action times compared to traditional schedules. This increase arose without an increase in surplus labor and with only a very small increase in the number of scheduled shifts. F2 thus offers managers a mechanism for reducing the burdens of implementing schedules in environments with relatively stable customer demand.

Third, our second new formulation of the WSSP, F3, yielded an $18.1 \%$ increase in the number of action times compared to traditional schedules across the 972 WSSPs we considered. This increase in action times came without an increase in surplus labor and with only a very modest increase in the number of scheduled shifts. F3 therefore provides managers a useful tool for developing schedules that facilitate effective real-time schedule changes, an important consideration in environments with relatively unstable customer demand.

We have observed that by using $\mathrm{F} 2$ or F3, instead of the traditional formulation F1, managers can exert a high degree of control over the number of action times, without raising schedule costs. Our fourth concluding observation is that managers' degree of control over action times will increase still further if they are willing to accept more costly labor schedules. Future research should be directed at elucidating this tradeoff relationship between schedule cost and action time control.

\section{References}

Agnihothri, S. A., Taylor, P. F. (1991) Staffing a centralized appointment scheduling department in Lourdes Hospital. Interfaces, $21,1-11$.

Andrews, B. H., Parsons, H. L. (1989) L. L. Bean chooses a telephone agent scheduling system. Interfaces, 19, $1-9$.

Brooke, A., Kendrick, D., Meeraus, A. (1992) GAMS, Release 2.25, $A$ User's Guide, The Scientific Press, South San Francisco, CA.

Dantzig, G. B. (1954) A comment on Edie's "Traffic delays at toll booths." Operations Research, 2, 339-341.

Easton, F. F., Rossin, D. F. (1991) Equivalent alternate solutions for the tour scheduling problem. Decision Sciences, 22, 985-1007.

Holloran, T. J., Byrn, J. E. (1986) United Airlines station manpower planning system. Interfaces, $16,39-50$.

IBM Corporation. (1991) Optimization Subroutine Library, Release 2, IBM Corporation, Kingston, NY.

Love, R. R., Jr., Hoey, J. M. (1990) Management science improves fast food operations. Interfaces, $20,21-29$.

Schindler, S., Semmel, T. (1993) Station staffing at Pan American World Airways. Interfaces, 23, 91-106. 
Thompson, G. M. (1995) Improved implicit optimal modeling of the shift scheduling problem. Management Science, 41, 595-607.

\section{Appendix A-Mathematical Programming Formulations of the Workforce Shift-Scheduling Problem}

We refer to the form of Dantzig's (1954) model where all shifts must be integers as F1. F1's objective is minimizing the cost of the schedule. We assume a shift's cost is a linear function of the number of planning intervals it works so that, in effect, any scheduled breaks are unpaid. Given this assumption, F1's objective is equivalent to both minimizing the total number of scheduled planning intervals worked and minimizing the surplus, unproductive staffing. F1 is:

$$
\operatorname{Min} Z_{F 1}=\sum_{n \in N} w_{n} x_{n}
$$

subject to

$$
\begin{gathered}
\sum_{n \in N} a_{n i} x_{n} \geq r_{i} \text { for } i \in I \\
x_{n} \geq 0 \text { and integer for } n \in N
\end{gathered}
$$

where

$N=$ set of shifts

$I=$ set of daily planning intervals

$w_{n}=$ number of planning intervals worked by shift $n$

$x_{n}=$ number of employees working shift $n$

$r_{i}=$ number of employees required in planning interval $i$

$$
a_{n i}=\left\{\begin{array}{l}
1, \text { if shift } \mathrm{n} \text { works planning interval } i \\
0, \text { otherwise }
\end{array}\right.
$$

Constraint set (2) ensures that sufficient staff are present in each planning interval, while constraint set (3) imposes the integrality of the variables measuring the number of employees working each shift.

F2 is our first new formulation of the WSSP. F2's primary objective, minimizing the cost of the labor schedule, takes complete precedence over its secondary objective of minimizing the number of action times. F2 is:

$$
\operatorname{Min} Z_{F 2}=P_{1} \sum_{n \in N} w_{n} x_{n}+P_{2} \sum_{\left\{i \in I_{i}>1\right\}} y_{i}
$$

subject to

$$
\begin{gathered}
\sum_{n \in\left\{S_{i} \cup F_{i} \cup B S_{i} \cup B F_{i}\right\}} x_{n} \leq M y_{i} \text { for }\{i \in I \mid i>1\} \\
y_{i} \in\{0,1\} \text { for }\{i \in I \mid i>1\}
\end{gathered}
$$

where

$$
\begin{aligned}
y_{i}= & 1, \text { if an action occurs at the start of interval } i \\
& \text { (end of interval } i-1 \text { ) } \\
& 0, \text { otherwise } \\
S_{i}= & \text { set of shifts that start at the beginning of plan- } \\
& \text { ning interval } i \\
F_{i}= & \text { set of shifts that finish at the end of planning } \\
& \text { interval } i-1 \\
B S_{i}= & \text { set of shifts with breaks that start at the begin- } \\
& \text { ning of planning interval } i \\
B F_{i}= & \text { set of shifts with breaks that finish at the end of } \\
& \text { planning interval } i-1 \\
M= & \text { a large positive integer; } \\
P_{i}= & \text { priority associated with goal } i \\
P_{1}> & >P_{2}
\end{aligned}
$$

Given constraint set (2), actions must occur at the start of planning interval one and at the end of the last planning interval. Thus, one need attempt only to minimize the number of action times occurring at the start of all planning intervals save the first. To see the logic of constraint set (5), note that an action at the end of planning interval $i-1$ occurs at the same time as an action at the start of planning interval $i$. As noted earlier, F2 is solved preemptively: first minimizing the labor cost, then minimizing the number of action times without raising the labor cost over its minimum possible value.

To further clarify F2, we consider a simple example. In this example, there are 10, hour-long planning intervals. Shifts contain five, six, seven, or eight hours of work. The shifts of seven and eight working hours have an hour-long meal break following the fourth hour of work, resulting in these shifts, respectively, being a total of eight and nine hours. Table A1 illustrates constraint sets (2) and (5) from F2. Variables $x_{1}$ through $x_{6}$ represent the five-hour shifts starting in hours one through six, respectively. Variables $x_{7}$ through $x_{11}$ represent the six-hour shifts starting in hours one through five, respectively. Variables $x_{12}$ through $x_{14}$ represent the seven-working-hour shifts starting in hours one through three, respectively. Finally, variables $x_{15}$ and $x_{16}$, respectively, represent the eight-working-hour shifts starting in hours one and two. Note that at the start of period six, the possible actions are: the completion of shift $x_{1}$, the start of shift $x_{6}$, the end of the break for shifts $x_{12}$ and $x_{15}$, and the start of the break for shifts $x_{13}$ and $x_{16}$.

Our second new formulation of the WSSP, F3, is identical to F2 except that F3 has a secondary objective of maximizing the number of action times. F3 is: 


$$
\operatorname{Min} Z_{F 3}=P_{1} \sum_{n \in N} w_{n} x_{n}-P_{2} \sum_{\{\in \in \mid i>1\}} y_{i}
$$

subject to

$$
\text { (2), (3), (5) and (6). }
$$

As with F2, F3 is solved preemptively. The primary objective of minimizing the schedule cost is satisfied first. Then, the number of action times is maximized without raising the schedule cost above its minimum possible level.

Though we investigate only F2 and F3, several other variants of these models are easily developed. For example, another variant of our new model, F4, would have a secondary objective of achieving a particular number of action times, T. F4, which uses two variables $\left(d_{a t}^{-}\right.$and $\left.d_{a t}^{+}\right)$to measure the deviation between the actual and desired number of action times, is:

$$
\operatorname{Min} Z_{F 4}=P_{1} \sum_{n \in N} w_{n} x_{n}-P_{2}\left(d_{a t}^{-}+d_{a t}^{+}\right)
$$

subject to

$$
\begin{aligned}
& \sum_{\{\in \in \mid i>1\}} y_{i}+d_{a t}^{-}-d_{a t}^{+}=T \\
& (2),(3),(5) \text { and }(6) .
\end{aligned}
$$

Finally, a fourth variant of our new model, F5, distinguishes between the types of actions. That is, F5 distinguishes between shift start actions, shift finish actions, break start actions, and break finish actions. F5 is:

$$
\begin{aligned}
\operatorname{Min} Z_{F 2}=P_{1} \sum_{n \in N} w_{n} x_{n}+ & P_{2} \sum_{\{i \in I \mid>1\}} y_{i}^{s s}+P_{3} \sum_{\{i \in \mid i>1\}} y_{i}^{s f} \\
& +P_{4} \sum_{\{i \in||>1\}} y_{i}^{b s}+P_{5} \sum_{\{\in \in \mid>1\}} y_{i}^{b f}
\end{aligned}
$$

subject to

$$
\begin{aligned}
& \sum_{n \in S_{i}} x_{n} \leq M y_{i}^{s s} \text { for } \quad\{i \in I \mid i>1\} \\
& \sum_{n \in F_{i}} x_{n} \leq M y_{i}^{s f} \text { for } \quad\{i \in I \mid i>1\}
\end{aligned}
$$

$$
\begin{aligned}
\sum_{n \in B S_{i}} x_{n} \leq M y_{i}^{b s} & \text { for } \quad\{i \in I \mid i>1\} \\
\sum_{n \in B F_{i}} x_{n} \leq M y_{i}^{b f} & \text { for } \quad\{i \in I \mid i>1\} \\
y_{i}^{s s} \in\{0,1\} & \text { for } \quad\{i \in I \mid i>1\} \\
y_{i}^{s f} \in\{0,1\} & \text { for } \quad\{i \in I \mid i>1\} \\
y_{i}^{b s} \in\{0,1\} & \text { for } \quad\{i \in I \mid i>1\} \\
y_{i}^{b f} \in\{0,1\} & \text { for } \quad\{i \in I \mid i>1\} \\
(2) \text { and } & \text { (3) }
\end{aligned}
$$

where

$$
\begin{aligned}
& y_{i}^{s s}=\left\{\begin{array}{l}
1, \text { if a shift starts at the beginning of interval } i \\
0, \text { otherwise }
\end{array}\right. \\
& y_{i}^{s f}=\left\{\begin{array}{l}
1, \text { if a shift finishes a the beginning of interval } \\
\quad i(\text { end of interval } i-1) \\
0, \text { otherwise }
\end{array}\right. \\
& y_{i}^{b s}=\left\{\begin{array}{l}
1, \text { if a break starts at the beginning of interval } i \\
0, \text { otherwise }
\end{array}\right. \\
& y_{i}^{b f}=\left\{\begin{array}{l}
1, \text { if a break finishes at the beginning of interval } \\
i(\text { end of interval } i-1) \\
0, \text { otherwise }
\end{array}\right.
\end{aligned}
$$

Obviously, using F5 requires that one specify the priorities associated with each type of action. However, the advantage of F5 is that it can allow even greater control and greater dispersion of action times than are possible with F2 or F3. Testing F5 is left to future research.

Though F2 and F3 are presented for the daily shift scheduling problem, they are readily extendible to the weekly tour scheduling problem. The tour scheduling problem has typically considered much less flexible scheduling environments than the ones we consider. However, our results with respect to scheduling flexibility lead us to believe that the tour scheduling forms of F2 and F3 will prove equally adept at controlling action times compared to the tour scheduling form of F1. 
Appendix B-Optimal Schedule for the Traditional Model, F1, for the Sample Fast Food Establishment

\begin{tabular}{|c|c|c|c|c|c|c|c|c|c|c|c|c|c|c|c|c|c|c|c|c|c|c|c|c|c|c|}
\hline \multirow{2}{*}{$\begin{array}{c}\text { Tine } \\
\text { Period }\end{array}$} & \multicolumn{22}{|c|}{ Employee } & \multirow{2}{*}{\multicolumn{4}{|c|}{ Charaoteristio }} \\
\hline & 81 & 2 & 3 & 4 & 5 & 6 & 7 & 8 & 9 & 10 & 11 & \begin{tabular}{|l|}
12 \\
\end{tabular} & 13 & 14 & 15 & 16 & 17 & 18 & \begin{tabular}{|l|}
19 \\
\end{tabular} & 20 & 21 & 22 & $\overline{A T}$ & & & \\
\hline $\begin{array}{l}6.00 \mathrm{am} \\
6.15 \mathrm{am} \\
\end{array}$ & $\begin{array}{l}w \\
w \\
\end{array}$ & $\begin{array}{l}w \\
w \\
w\end{array}$ & $\begin{array}{l}w \\
w \\
w\end{array}$ & $w$ & & & & & & & & & & & & & & & & & & & $\begin{array}{l}\mathrm{A} \\
\mathrm{A} \\
\end{array}$ & $\begin{array}{l}3 \\
4 \\
\end{array}$ & $\begin{array}{l}3 \\
4 \\
\end{array}$ & \\
\hline $\begin{array}{l}6.30 \mathrm{am} \\
6.45 \mathrm{am}\end{array}$ & $w$ & $w$ & $w$ & $\begin{array}{l}w \\
w\end{array}$ & $w$ & $w$ & & & & & & & & & & & & & & & & & A & 5 & 5 & \\
\hline $\begin{array}{l}7.00 \mathrm{am} \\
7.15 \mathrm{am}\end{array}$ & $\begin{array}{l}w \\
w\end{array}$ & $w$ & $\begin{array}{l}w \\
w\end{array}$ & $w$ & $\begin{array}{l}w \\
w\end{array}$ & $w$ & $\mathbf{w}$ & & & & & & & & & & & & & & & & $A$ & $\begin{array}{l}6 \\
7\end{array}$ & $\begin{array}{l}\frac{2}{6} \\
7\end{array}$ & \\
\hline $\begin{array}{l}7.30 \mathrm{am} \\
7.45 \mathrm{am} \\
\end{array}$ & $\begin{array}{l}w \\
w\end{array}$ & $\begin{array}{l}w \\
w\end{array}$ & $\begin{array}{l}w \\
w\end{array}$ & $\begin{array}{l}\mathbf{w} \\
\mathbf{w}\end{array}$ & $\begin{array}{l}w \\
w\end{array}$ & $\begin{array}{l}w \\
w \\
\end{array}$ & $\begin{array}{l}w \\
w\end{array}$ & & & & & & & & & & & & & & & & & 7 & $\begin{array}{l}7 \\
7\end{array}$ & \\
\hline $\begin{array}{l}8: 00 \mathrm{am} \\
8: 15 \mathrm{am}\end{array}$ & $\begin{array}{l}w \\
b\end{array}$ & $\begin{array}{l}w \\
w\end{array}$ & $\begin{array}{l}w \\
w\end{array}$ & $\begin{array}{l}w \\
w\end{array}$ & $\begin{array}{l}w \\
w\end{array}$ & $\begin{array}{l}w \\
w\end{array}$ & $\begin{array}{l}w \\
w\end{array}$ & & & & & & & & & & & & & & & & A & $\begin{array}{l}7 \\
6\end{array}$ & $\begin{array}{l}7 \\
6\end{array}$ & \\
\hline $\begin{array}{l}8: 30 \mathrm{am} \\
8: 45 \mathrm{am}\end{array}$ & $\begin{array}{l}b \\
b\end{array}$ & $\begin{array}{l}w \\
b\end{array}$ & $\begin{array}{l}w \\
w\end{array}$ & $\begin{array}{l}w \\
w\end{array}$ & $\begin{array}{l}w \\
w\end{array}$ & $\left.\begin{array}{l}w \\
w\end{array}\right]$ & $\begin{array}{l}w \\
w\end{array}$ & & & & & & & & & & & & & & & & A & $\begin{array}{l}6 \\
5\end{array}$ & $\begin{array}{l}6 \\
5\end{array}$ & \\
\hline $\begin{array}{l}9: 00 \mathrm{am} \\
9: 15 \mathrm{am}\end{array}$ & $\begin{array}{c}\mathrm{b} \\
\mathrm{w}\end{array}$ & $\begin{array}{l}b \\
b\end{array}$ & $\begin{array}{l}\mathrm{w} \\
\mathrm{b}\end{array}$ & $\begin{array}{l}w \\
w\end{array}$ & $\begin{array}{l}w \\
w\end{array}$ & $\begin{array}{l}w \\
w\end{array}$ & $w$ & & & & & & & & & & & & & & & & A & $\begin{array}{l}5 \\
5\end{array}$ & $\begin{array}{l}5 \\
5\end{array}$ & \\
\hline $\begin{array}{l}930 \mathrm{amr} \\
945 \mathrm{am} \\
\end{array}$ & $\begin{array}{l}w \\
w \\
\end{array}$ & $\begin{array}{l}b \\
w \\
\end{array}$ & $\begin{array}{l}\mathrm{b} \\
\mathrm{b}\end{array}$ & $\begin{array}{l}\mathrm{b} \\
\mathrm{b} \\
\end{array}$ & $\begin{array}{l}\mathbf{w} \\
\mathrm{b} \\
\end{array}$ & $\begin{array}{l}w \\
w \\
\end{array}$ & $\begin{array}{l}w \\
w \\
\end{array}$ & & & & & & & & & & & & & & & & $\begin{array}{l}\mathrm{A} \\
\mathrm{A}\end{array}$ & $\begin{array}{l}4 \\
4 \\
\end{array}$ & $\begin{array}{l}4 \\
4 \\
\end{array}$ & \\
\hline $\begin{array}{l}10.00 \mathrm{am} \\
10: 15 \mathrm{am}\end{array}$ & $\begin{array}{l}w \\
w\end{array}$ & $\begin{array}{l}w \\
w\end{array}$ & $\begin{array}{l}b \\
w\end{array}$ & $\begin{array}{l}\mathrm{b} \\
\mathrm{b}\end{array}$ & $\begin{array}{l}b \\
b\end{array}$ & $w$ & $\begin{array}{l}\mathbf{w} \\
\mathbf{w}\end{array}$ & $\begin{array}{l}w \\
w\end{array}$ & $\begin{array}{l}w \\
w\end{array}$ & & & & & & & & & & & & & & A & 6 & $\begin{array}{l}6 \\
7\end{array}$ & \\
\hline $\begin{array}{l}10: 30 \mathrm{am} \\
10: 45 \mathrm{am}\end{array}$ & $\begin{array}{l}w \\
w\end{array}$ & $\begin{array}{l}w \\
w\end{array}$ & $\begin{array}{l}w \\
w\end{array}$ & $\begin{array}{l}\mathbf{w} \\
\mathbf{w}\end{array}$ & $\begin{array}{l}b \\
w\end{array}$ & $\begin{array}{l}b \\
b\end{array}$ & $\begin{array}{l}b \\
b\end{array}$ & $\begin{array}{l}w \\
w\end{array}$ & $\begin{array}{l}w \\
w\end{array}$ & & & & & & & & & & & & & & $\begin{array}{l}\bar{A} \\
A\end{array}$ & $\begin{array}{l}6 \\
6 \\
6\end{array}$ & $\begin{array}{l}6 \\
?\end{array}$ & 1 \\
\hline $\begin{array}{l}11: 00 \mathrm{am} \\
11: 15 \mathrm{am} \\
\end{array}$ & $\begin{array}{l}w \\
w \\
\end{array}$ & $\begin{array}{l}w \\
w \\
\end{array}$ & $\begin{array}{l}w \\
w \\
\end{array}$ & $\begin{array}{l}w \\
w \\
\end{array}$ & $\begin{array}{l}w \\
w \\
w\end{array}$ & $\begin{array}{l}\mathrm{b} \\
\mathrm{b} \\
\end{array}$ & $\begin{array}{l}\mathrm{b} \\
\mathrm{b}\end{array}$ & \begin{tabular}{|l}
$b$ \\
$b$ \\
\end{tabular} & $\begin{array}{l}w \\
w \\
w\end{array}$ & & & & & & & & & & & & & & A & $\begin{array}{l}6 \\
6\end{array}$ & $\begin{array}{l}6 \\
6 \\
6\end{array}$ & \\
\hline $\begin{array}{l}11: 30 \mathrm{am} \\
11: 45 \mathrm{am}\end{array}$ & $\begin{array}{l}\mathbf{w} \\
\mathbf{w}\end{array}$ & $\begin{array}{l}w \\
w\end{array}$ & $\begin{array}{l}w \\
w\end{array}$ & $w$ & $\begin{array}{l}w \\
w\end{array}$ & $\begin{array}{l}\mathbf{w} \\
\mathbf{w}\end{array}$ & $\begin{array}{l}w \\
w\end{array}$ & $\begin{array}{l}b \\
b\end{array}$ & $w$ & $w$ & $w$ & w & $w$ & & & & & & & & & & A & 9 & 9 & \\
\hline $\begin{array}{c}\text { noon } \\
12: 15 \mathrm{pm}\end{array}$ & $\begin{array}{l}w \\
w\end{array}$ & $\begin{array}{l}w \\
w\end{array}$ & $\begin{array}{l}w \\
w\end{array}$ & $\begin{array}{l}w \\
w\end{array}$ & $\begin{array}{l}w \\
w\end{array}$ & $w$ & $\begin{array}{l}w \\
w\end{array}$ & $\begin{array}{l}w \\
w\end{array}$ & $\begin{array}{l}w \\
w\end{array}$ & $\begin{array}{l}w \\
w\end{array}$ & $\begin{array}{l}w \\
w\end{array}$ & $\begin{array}{l}w \\
w\end{array}$ & $\begin{array}{l}w \\
w\end{array}$ & $\begin{array}{l}w \\
w\end{array}$ & $\begin{array}{l}w \\
w\end{array}$ & & & & & & & & A & \begin{tabular}{l|}
15 \\
15
\end{tabular} & $\begin{array}{l}15 \\
15\end{array}$ & \\
\hline $\begin{array}{l}12: 30 \mathrm{pm} \\
12: 45 \mathrm{pm}\end{array}$ & $w$ & $w$ & $\begin{array}{l}w \\
w \\
\end{array}$ & $\begin{array}{l}w \\
w\end{array}$ & $\begin{array}{l}w \\
w\end{array}$ & $\begin{array}{l}w \\
w\end{array}$ & \begin{tabular}{l|}
$w$ \\
$w$
\end{tabular} & $\begin{array}{l}w \\
w\end{array}$ & $\begin{array}{l}w \\
w\end{array}$ & $\begin{array}{l}w \\
w\end{array}$ & $\begin{array}{l}w \\
w\end{array}$ & $\begin{array}{l}w \\
w\end{array}$ & $\begin{array}{l}w \\
w\end{array}$ & $w$ & $\begin{array}{l}\mathbf{w} \\
\mathbf{w}\end{array}$ & & & & & & & & A & $\begin{array}{l}15 \\
13\end{array}$ & $\begin{array}{l}15 \\
13 \\
\end{array}$ & \\
\hline $\begin{array}{l}1: 00 \mathrm{pm} \\
1: 15 \mathrm{pm} \\
\end{array}$ & & & & $w$ & $\begin{array}{l}w \\
w\end{array}$ & $\begin{array}{l}w \\
w \\
\end{array}$ & $\begin{array}{l}w \\
w\end{array}$ & $\begin{array}{l}w \\
w\end{array}$ & $\begin{array}{l}w \\
w \\
\end{array}$ & $\begin{array}{l}w \\
w \\
\end{array}$ & $\begin{array}{l}w \\
w\end{array}$ & $\begin{array}{l}w \\
w\end{array}$ & $\begin{array}{l}w \\
w\end{array}$ & $\begin{array}{l}w \\
w\end{array}$ & $\begin{array}{l}w \\
w \\
w\end{array}$ & & & & & & & & $\begin{array}{l}A \\
A\end{array}$ & $\begin{array}{l}12 \\
11 \\
\end{array}$ & $\begin{array}{l}12 \\
11\end{array}$ & \\
\hline $\begin{array}{l}1: 30 \mathrm{pm} \\
1: 45 \mathrm{pm}\end{array}$ & & & & & & & $w$ & $w$ & $\begin{array}{l}w \\
b\end{array}$ & $\begin{array}{l}w \\
w\end{array}$ & $\begin{array}{l}w \\
w\end{array}$ & $\begin{array}{l}w \\
w\end{array}$ & $w$ & $\begin{array}{l}w \\
w\end{array}$ & $\begin{array}{l}w \\
w\end{array}$ & & & & & & & & $\begin{array}{l}A \\
A\end{array}$ & 9 & 9 & \\
\hline $\begin{array}{l}2: 00 \mathrm{pm} \\
2: 15 \mathrm{pm} \\
\end{array}$ & & & & & & & & $\begin{array}{l}w \\
w\end{array}$ & $\begin{array}{l}b \\
b\end{array}$ & $\begin{array}{l}b \\
b \\
\end{array}$ & $\begin{array}{l}b \\
b\end{array}$ & $\begin{array}{l}w \\
w\end{array}$ & $\begin{array}{l}w \\
w\end{array}$ & $\begin{array}{l}w \\
w \\
\end{array}$ & $\begin{array}{r}w \\
w \\
\end{array}$ & & & & & & & & A & $\begin{array}{l}5 \\
5 \\
\end{array}$ & $\begin{array}{l}5 \\
5 \\
\end{array}$ & \\
\hline $\begin{array}{l}2.30 \mathrm{pm} \\
2: 45 \mathrm{pm} \\
\end{array}$ & & & & & & & & $\begin{array}{l}w \\
w\end{array}$ & $\begin{array}{l}b \\
w \\
\end{array}$ & $\begin{array}{l}\mathrm{b} \\
\mathrm{b}\end{array}$ & $\begin{array}{l}\mathrm{b} \\
\mathrm{b}\end{array}$ & $\begin{array}{l}w \\
w\end{array}$ & $\begin{array}{l}w \\
w\end{array}$ & $\begin{array}{l}w \\
w\end{array}$ & $\begin{array}{l}w \\
w\end{array}$ & & & & & & & & A & $\begin{array}{l}5 \\
6 \\
\end{array}$ & $\begin{array}{l}5 \\
6\end{array}$ & \\
\hline $\begin{array}{l}3.00 \mathrm{pm} \\
3.15 \mathrm{pm} \\
\end{array}$ & & & & & & & & $\begin{array}{l}w \\
w\end{array}$ & $\begin{array}{l}w \\
w\end{array}$ & $\begin{array}{l}w \\
w\end{array}$ & $\begin{array}{l}w \\
w\end{array}$ & $\begin{array}{l}b \\
b\end{array}$ & $\begin{array}{l}w \\
w\end{array}$ & $w$ & $\begin{array}{l}w \\
w\end{array}$ & & & & & & & & A & $\begin{array}{l}7 \\
7\end{array}$ & $\begin{array}{l}7 \\
7 \\
\end{array}$ & \\
\hline $\begin{array}{l}3: 30 \mathrm{pm} \\
3: 45 \mathrm{pm}\end{array}$ & & & & & & & & $\begin{array}{l}w \\
w\end{array}$ & $\begin{array}{l}w \\
w \\
w\end{array}$ & $\begin{array}{l}w \\
w\end{array}$ & $\begin{array}{l}w \\
w\end{array}$ & $\begin{array}{l}\mathrm{b} \\
\mathrm{b}\end{array}$ & $\begin{array}{l}\mathrm{b} \\
\mathrm{b}\end{array}$ & $\begin{array}{l}w \\
b\end{array}$ & $\mathbf{w}$ & \begin{tabular}{|l}
$w$ \\
$w$
\end{tabular} & & & & & & & $\begin{array}{l}\text { A } \\
A\end{array}$ & $\begin{array}{l}7 \\
6\end{array}$ & $\begin{array}{l}7 \\
6\end{array}$ & \\
\hline $\begin{array}{l}4: 00 \mathrm{pm} \\
4: 15 \mathrm{pm} \\
\end{array}$ & & & & & & & & & $\begin{array}{l}w \\
w \\
\end{array}$ & $\begin{array}{l}w \\
w\end{array}$ & $\begin{array}{l}w \\
w\end{array}$ & $\begin{array}{l}w \\
w\end{array}$ & $\begin{array}{l}b \\
b\end{array}$ & $\begin{array}{l}b \\
b\end{array}$ & $\begin{array}{l}b \\
b\end{array}$ & $\begin{array}{l}w \\
w\end{array}$ & $\begin{array}{l}w \\
w\end{array}$ & & & & & & $\mathrm{~A}$ & $\begin{array}{l}6 \\
6 \\
6\end{array}$ & $\begin{array}{l}6 \\
6 \\
6\end{array}$ & \\
\hline $\begin{array}{l}4: 30 \mathrm{pm} \\
4: 46 \mathrm{pm}\end{array}$ & & & & & & & & & $\begin{array}{l}w \\
w\end{array}$ & $\begin{array}{l}\mathbf{w} \\
\mathbf{w}\end{array}$ & $\begin{array}{l}w \\
w\end{array}$ & $\begin{array}{c}w \\
w\end{array}$ & $\begin{array}{l}w \\
w\end{array}$ & $\begin{array}{l}b \\
w\end{array}$ & $\begin{array}{l}b \\
b\end{array}$ & $\begin{array}{c}w \\
b\end{array}$ & $\begin{array}{c}w \\
w\end{array}$ & & & & & & $\begin{array}{l}\mathrm{A} \\
\bar{A}\end{array}$ & $\begin{array}{l}7 \\
7\end{array}$ & $\begin{array}{l}7 \\
7\end{array}$ & \\
\hline $\begin{array}{l}5: 00 \mathrm{pm} \\
5: 15 \mathrm{pm} \\
\end{array}$ & & & & & & & & & $\begin{array}{l}w \\
w\end{array}$ & $\begin{array}{l}w \\
w\end{array}$ & $\begin{array}{l}w \\
w\end{array}$ & $\begin{array}{l}w \\
w \\
\end{array}$ & $\begin{array}{l}w \\
w\end{array}$ & $\begin{array}{l}w \\
w\end{array}$ & $\begin{array}{l}w \\
w\end{array}$ & $\begin{array}{l}\mathrm{b} \\
\mathrm{b}\end{array}$ & $\begin{array}{l}w \\
w \\
\end{array}$ & $w$ & $w$ & & & & $\begin{array}{l}\bar{A} \\
A\end{array}$ & $\begin{array}{l}8 \\
10 \\
\end{array}$ & $\begin{array}{l}8 \\
10\end{array}$ & \\
\hline $\begin{array}{l}5: 30 \mathrm{pm} \\
5: 45 \mathrm{pm} \\
\end{array}$ & & & & & & & & & $\begin{array}{l}w \\
w\end{array}$ & $\begin{array}{l}w \\
w\end{array}$ & $\begin{array}{l}w \\
w\end{array}$ & $\begin{array}{l}w \\
w \\
w\end{array}$ & $\begin{array}{l}w \\
w\end{array}$ & $w$ & $\begin{array}{l}w \\
w\end{array}$ & $\begin{array}{l}b \\
w \\
w\end{array}$ & $\begin{array}{l}w \\
w\end{array}$ & $\begin{array}{c}\bar{w} \\
w \\
\end{array}$ & $\begin{array}{l}w \\
w\end{array}$ & $\begin{array}{l}w \\
w\end{array}$ & & & $\begin{array}{l}\mathrm{A} \\
\mathrm{A}\end{array}$ & $\begin{array}{l}11 \\
12 \\
\end{array}$ & $\begin{array}{l}11 \\
12\end{array}$ & \\
\hline $\begin{array}{r}6: 00 \mathrm{pm} \\
6: 15 \mathrm{pm} \\
\end{array}$ & & & & & & & & & w & $\begin{array}{l}w \\
w \\
\end{array}$ & $\begin{array}{l}w \\
w\end{array}$ & $\begin{array}{l}w \\
w\end{array}$ & $\begin{array}{l}w \\
w\end{array}$ & $\begin{array}{l}w \\
w\end{array}$ & $\begin{array}{l}w \\
w\end{array}$ & $\begin{array}{l}w \\
w \\
\end{array}$ & $\begin{array}{l}w \\
w\end{array}$ & $\begin{array}{l}w \\
w\end{array}$ & $\begin{array}{l}w \\
w \\
\end{array}$ & $\begin{array}{l}w \\
w\end{array}$ & & & A & $\begin{array}{l}12 \\
11 \\
\end{array}$ & $\begin{array}{l}12 \\
11\end{array}$ & \\
\hline $\begin{array}{l}6: 30 \mathrm{pm} \\
6: 45 \mathrm{pm} \\
\end{array}$ & & & & & & & & & & $w$ & $\begin{array}{l}w \\
w\end{array}$ & $w$ & $\begin{array}{l}w \\
w\end{array}$ & $w$ & $\begin{array}{l}w \\
w\end{array}$ & $\begin{array}{l}w \\
w\end{array}$ & $\begin{array}{l}b \\
b\end{array}$ & $\begin{array}{l}\mathbf{w} \\
\mathbf{w}\end{array}$ & $\begin{array}{l}w \\
w\end{array}$ & $\begin{array}{l}w \\
w\end{array}$ & & & A & $\begin{array}{l}10 \\
10\end{array}$ & $\begin{array}{l}10 \\
10\end{array}$ & \\
\hline $\begin{array}{l}7.00 \mathrm{pm} \\
7: 15 \mathrm{pm} \\
\end{array}$ & & & & & & & & & & & $\begin{array}{l}w \\
w\end{array}$ & $\begin{array}{l}w \\
w \\
\end{array}$ & $\begin{array}{l}w \\
w\end{array}$ & $\begin{array}{l}w \\
w\end{array}$ & $\begin{array}{l}w \\
w\end{array}$ & $\begin{array}{l}w \\
w\end{array}$ & $\begin{array}{l}\mathrm{b} \\
\mathrm{b}\end{array}$ & $\begin{array}{l}w \\
w\end{array}$ & $\begin{array}{l}w \\
w\end{array}$ & $\begin{array}{c}w \\
w\end{array}$ & & & $\bar{A}$ & $\begin{array}{l}9 \\
9\end{array}$ & 9 & \\
\hline \begin{tabular}{l|}
$7.30 \mathrm{pm}$ \\
$7.45 \mathrm{pm}$ \\
\end{tabular} & & & & & & & & & & & & & & $w$ & $\begin{array}{l}w \\
w\end{array}$ & $\begin{array}{l}w \\
w \\
\end{array}$ & $\begin{array}{l}w \\
w\end{array}$ & $\begin{array}{l}b \\
b\end{array}$ & $\begin{array}{l}w \\
w\end{array}$ & $\begin{array}{l}w \\
w\end{array}$ & $\begin{array}{l}w \\
w \\
\end{array}$ & $\begin{array}{l}w \\
w\end{array}$ & $\bar{A}$ & $\begin{array}{l}8 \\
8 \\
\end{array}$ & $\begin{array}{l}8 \\
8 \\
\end{array}$ & \\
\hline $\begin{array}{l}8: 00 \mathrm{pm} \\
8: 15 \mathrm{pm}\end{array}$ & & & & & & & & & & & & & & $\begin{array}{l}w \\
w\end{array}$ & $\begin{array}{l}w \\
w\end{array}$ & $\begin{array}{l}w \\
w\end{array}$ & $\begin{array}{l}w \\
w\end{array}$ & $\begin{array}{l}b \\
b\end{array}$ & $\begin{array}{l}w \\
w\end{array}$ & $\begin{array}{l}w \\
w\end{array}$ & $\begin{array}{l}w \\
w\end{array}$ & $w$ & & $\begin{array}{l}8 \\
8\end{array}$ & $\begin{array}{l}8 \\
8\end{array}$ & \\
\hline $\begin{array}{l}\text { 8:30 pm } \\
\text { 8:45 pm }\end{array}$ & & & & & & & & & & & & & & $\begin{array}{l}w \\
w \\
\end{array}$ & $\begin{array}{l}\mathbf{w} \\
\mathbf{w}\end{array}$ & $\begin{array}{l}\mathrm{w} \\
\mathrm{w} \\
\end{array}$ & $\begin{array}{l}w \\
w\end{array}$ & $\begin{array}{l}w \\
w\end{array}$ & $\begin{array}{l}\mathrm{b} \\
\mathrm{b}\end{array}$ & $\begin{array}{l}b \\
b\end{array}$ & $\begin{array}{l}w \\
w\end{array}$ & $\begin{array}{l}w \\
w\end{array}$ & $\bar{A}$ & $\begin{array}{l}7 \\
7 \\
\end{array}$ & $\begin{array}{l}7 \\
7\end{array}$ & \\
\hline $\begin{array}{l}9: 00 \mathrm{pm} \\
9: 15 \mathrm{pm} \\
\end{array}$ & & & & & & & & & & & & & & $\begin{array}{l}w \\
w\end{array}$ & $\begin{array}{l}w \\
w\end{array}$ & $\begin{array}{l}w \\
w \\
\end{array}$ & $\begin{array}{l}w \\
w\end{array}$ & $\begin{array}{l}w \\
w\end{array}$ & $\begin{array}{l}b \\
b\end{array}$ & $\begin{array}{l}b \\
b\end{array}$ & $\begin{array}{l}w \\
w\end{array}$ & $\begin{array}{l}w \\
w \\
\end{array}$ & & $\begin{array}{l}7 \\
2 \\
\end{array}$ & $\begin{array}{l}7 \\
7 \\
\end{array}$ & \\
\hline $\begin{array}{l}9: 30 \mathrm{pm} \\
9: 45 \mathrm{pm}\end{array}$ & & & & & & & & & & & & & & $w$ & $\begin{array}{l}w \\
w\end{array}$ & $\begin{array}{l}w \\
w\end{array}$ & $w$ & $\begin{array}{l}w \\
w\end{array}$ & $\mathbf{w}$ & $w$ & $\begin{array}{l}b \\
b\end{array}$ & $\begin{array}{l}\mathrm{b} \\
\mathrm{b}\end{array}$ & $\bar{A}$ & $\begin{array}{l}? \\
7\end{array}$ & $\frac{7}{7}$ & \\
\hline $\begin{array}{l}10: 00 \mathrm{pm} \\
10: 15 \mathrm{pm}\end{array}$ & & & & & & & & & & & & & & $\begin{array}{l}w \\
w \\
\end{array}$ & $\begin{array}{l}\mathbf{w} \\
\mathbf{w}\end{array}$ & $\begin{array}{l}w \\
w\end{array}$ & $\begin{array}{l}w \\
w\end{array}$ & $\begin{array}{l}w \\
w\end{array}$ & $\begin{array}{l}w \\
w\end{array}$ & $\begin{array}{l}w \\
w \\
\end{array}$ & $\begin{array}{l}b \\
b\end{array}$ & $\begin{array}{l}\mathrm{b} \\
\mathrm{b}\end{array}$ & & $\begin{array}{l}7 \\
7 \\
\end{array}$ & $\begin{array}{l}7 \\
7 \\
\end{array}$ & \\
\hline \begin{tabular}{l|}
$10: 30 \mathrm{pm}$ \\
$10: 45 \mathrm{pm}$ \\
\end{tabular} & & & & & & & & & & & & & & & & & $\begin{array}{l}w \\
w \\
\end{array}$ & $\begin{array}{l}w \\
w\end{array}$ & $\begin{array}{c}w \\
w\end{array}$ & $w$ & $\begin{array}{l}w \\
w \\
\end{array}$ & $\begin{array}{l}w \\
w\end{array}$ & A & $\begin{array}{l}6 \\
6 \\
\end{array}$ & $\begin{array}{l}6 \\
6 \\
\end{array}$ & \\
\hline $\begin{array}{l}11: 00 \mathrm{pm} \\
11: 15 \mathrm{pm} \\
\end{array}$ & & & & & & & & & & & & & & & & & $\begin{array}{l}w \\
w\end{array}$ & $\begin{array}{l}w \\
w\end{array}$ & $\begin{array}{l}w \\
w\end{array}$ & $w$ & $\begin{array}{l}w \\
w\end{array}$ & $\begin{array}{l}w \\
w\end{array}$ & & $\begin{array}{l}6 \\
6 \\
\end{array}$ & $\begin{array}{l}6 \\
6 \\
\end{array}$ & \\
\hline $\begin{array}{l}11: 30 \mathrm{pm} \\
11: 45 \mathrm{pm}\end{array}$ & & & & & & & & & & & & & & & & & $w$ & $\begin{array}{l}w \\
w\end{array}$ & $w$ & $\begin{array}{l}w \\
w\end{array}$ & $\begin{array}{l}w \\
w\end{array}$ & $\begin{array}{l}w \\
w \\
\end{array}$ & A & $\begin{array}{l}6 \\
5 \\
\end{array}$ & $\begin{array}{l}6 \\
5 \\
\end{array}$ & \\
\hline $\begin{array}{l}\text { midnight } \\
\text { 12:15 am } \\
\end{array}$ & & & & & & & & & & & & & & & & & & $\begin{array}{l}w \\
w\end{array}$ & $\begin{array}{l}w \\
w\end{array}$ & $\begin{array}{c}w \\
w\end{array}$ & $\begin{array}{l}w \\
w \\
w\end{array}$ & $\begin{array}{l}w \\
w\end{array}$ & & $\begin{array}{l}5 \\
5 \\
\end{array}$ & $\begin{array}{l}5 \\
5 \\
\end{array}$ & \\
\hline $\begin{array}{l}12: 30 \mathrm{am} \\
12: 45 \mathrm{am} \\
\end{array}$ & & & & & & & & & & & & & & & & & & $\begin{array}{l}w \\
w\end{array}$ & $\begin{array}{l}w \\
w\end{array}$ & $\begin{array}{l}w \\
w\end{array}$ & $\begin{array}{l}w \\
w\end{array}$ & $\begin{array}{l}w \\
w\end{array}$ & & $\begin{array}{l}5 \\
5 \\
\end{array}$ & $\begin{array}{l}5 \\
5\end{array}$ & \\
\hline $\begin{array}{l}1.00 \mathrm{am} \\
1.15 \mathrm{am} \\
\end{array}$ & & & & & & & & & & & & & & & & & & & $\begin{array}{l}w \\
w\end{array}$ & $w$ & $w$ & $\begin{array}{l}w \\
w\end{array}$ & A & $\begin{array}{l}4 \\
4\end{array}$ & $\begin{array}{l}4 \\
4\end{array}$ & \\
\hline $\begin{array}{l}1: 30 \mathrm{am} \\
1: 45 \mathrm{am} \\
\end{array}$ & & & & & & & & & & & & & & & & & & & & $\begin{array}{l}w \\
w\end{array}$ & $\begin{array}{l}w \\
w\end{array}$ & $\begin{array}{l}w \\
w\end{array}$ & $\bar{A}$ & $\begin{array}{r}3 \\
3 \\
\end{array}$ & $\begin{array}{l}3 \\
3 \\
\end{array}$ & \\
\hline Total & & & & & & & & & & & & & & & & & & & & & & & 46 & 575 & 576 & \\
\hline
\end{tabular}

$\mathrm{W}=\mathrm{a}$ work period; $\mathrm{B}=\mathrm{a}$ break period; $\mathrm{AT}=\mathrm{A}$ if an action occurs at the start of the period; $\mathrm{Rq}=$ number of employees required; Wk $=$ number of employees scheduled; Su number of surplus enployees 
Appendix C-Optimal Schedule for the New Model, F2, for the Sample Fast Food Establishment

\begin{tabular}{|c|c|c|c|c|c|c|c|c|c|c|c|c|c|c|c|c|c|c|c|c|c|c|c|c|c|c|}
\hline Time & & & & & & & & & & & Emp & loyee & & & & & & & & & & & & Chara & deristic & \\
\hline Period & 1 & 2 & 3 & 4 & 5 & 6 & 7 & 8 & 9 & 10 & 11 & 12 & 13 & 14 & 15 & 16 & 17 & 18 & 19 & 20 & 21 & 22 & $\overline{A T}$ & I $\mathrm{gg}$ & $w_{k}$ & su \\
\hline \begin{tabular}{|l|}
$6: 00 \mathrm{am}$ \\
$6: 15 \mathrm{am}$ \\
\end{tabular} & $\begin{array}{l}w \\
w \\
w\end{array}$ & $\begin{array}{l}w \\
w\end{array}$ & $\begin{array}{l}w \\
w\end{array}$ & $w$ & & & & & & & & & & & & & & & & & & & $\begin{array}{l}\text { A } \\
A\end{array}$ & \begin{tabular}{|l}
3 \\
4
\end{tabular} & $\begin{array}{l}3 \\
4 \\
\end{array}$ & \\
\hline \begin{tabular}{|l|}
$6: 30 \mathrm{am}$ \\
$6: 45 \mathrm{am}$ \\
\end{tabular} & $\begin{array}{l}w \\
w \\
\end{array}$ & $\begin{array}{l}w \\
w \\
\end{array}$ & $\begin{array}{l}w \\
w\end{array}$ & $\begin{array}{l}w \\
w\end{array}$ & $\begin{array}{l}w \\
w\end{array}$ & $w$ & & & & & & & & & & & & & & & & & $\begin{array}{l}\mathrm{A} \\
\mathrm{A}\end{array}$ & $\begin{array}{l}5 \\
6\end{array}$ & $\begin{array}{l}5 \\
6\end{array}$ & \\
\hline $\begin{array}{l}7: 00 \mathrm{am} \\
7.15 \mathrm{am} \\
\end{array}$ & $\begin{array}{l}w \\
w \\
\end{array}$ & $\begin{array}{l}w \\
w\end{array}$ & $\begin{array}{l}w \\
w\end{array}$ & $\begin{array}{l}w \\
w\end{array}$ & $\begin{array}{l}w \\
w\end{array}$ & $\begin{array}{l}w \\
w\end{array}$ & $w$ & & & & & & & & & & & & & & & & A & \begin{tabular}{|l}
6 \\
7 \\
\end{tabular} & $\begin{array}{l} \\
3 \\
\end{array}$ & \\
\hline $\begin{array}{l}7: 30 \mathrm{am} \\
7: 45 \mathrm{am} \\
\end{array}$ & $\begin{array}{l}w \\
w \\
\end{array}$ & $\begin{array}{l}w \\
w \\
w\end{array}$ & $\begin{array}{l}w \\
w\end{array}$ & $\begin{array}{l}w \\
w\end{array}$ & $\begin{array}{l}w \\
w\end{array}$ & $\begin{array}{l}w \\
w \\
\end{array}$ & $\begin{array}{l}w \\
w\end{array}$ & & & & & & & & & & & & & & & & & $\begin{array}{l}7 \\
7 \\
\end{array}$ & $\begin{array}{l}7 \\
7 \\
\end{array}$ & \\
\hline $\begin{array}{l}8: 00 \mathrm{am} \\
8: 15 \mathrm{am} \\
\end{array}$ & $\begin{array}{l}w \\
b\end{array}$ & $\begin{array}{l}w \\
w\end{array}$ & $\begin{array}{l}w \\
w\end{array}$ & $\begin{array}{l}w \\
w\end{array}$ & $\begin{array}{l}w \\
w\end{array}$ & $\begin{array}{l}w \\
w\end{array}$ & $\begin{array}{l}w \\
w\end{array}$ & & & & & & & & & & & & & & & & A & $\begin{array}{l}7 \\
6 \\
\end{array}$ & $\begin{array}{l}7 \\
6\end{array}$ & \\
\hline $\begin{array}{l}8: 30 \mathrm{am} \\
8.45 \mathrm{am} \\
\end{array}$ & $\begin{array}{l}\mathrm{b} \\
\mathrm{b} \\
\end{array}$ & $\begin{array}{l}w \\
w \\
\end{array}$ & $\begin{array}{l}w \\
w\end{array}$ & $\begin{array}{l}w \\
w\end{array}$ & $\begin{array}{l}w \\
w\end{array}$ & $\begin{array}{l}w \\
w\end{array}$ & $\begin{array}{l}w \\
w\end{array}$ & & & & & & & & & & & & & & & & & $\begin{array}{l}6 \\
5 \\
\end{array}$ & $\begin{array}{l}6 \\
6 \\
\end{array}$ & \\
\hline $\begin{array}{l}9: 00 \mathrm{am} \\
9: 16 \mathrm{am} \\
\end{array}$ & $\begin{array}{l}b \\
w \\
\end{array}$ & $\begin{array}{l}\mathrm{b} \\
\mathrm{b} \\
\end{array}$ & $\begin{array}{l}\mathrm{b} \\
\mathrm{b}\end{array}$ & $\begin{array}{l}w \\
b\end{array}$ & $\begin{array}{l}\mathbf{w} \\
\mathbf{w}\end{array}$ & $\begin{array}{l}w \\
w\end{array}$ & $\begin{array}{l}w \\
w\end{array}$ & $\begin{array}{l}w \\
w\end{array}$ & & & & & & & & & & & & & & & $\begin{array}{l}A \\
A\end{array}$ & $\begin{array}{l}5 \\
5 \\
\end{array}$ & $\begin{array}{l}5 \\
5 \\
\end{array}$ & \\
\hline \begin{tabular}{|l|}
$9: 30 \mathrm{am}$ \\
$9: 45 \mathrm{am}$ \\
\end{tabular} & $\begin{array}{l}w \\
w \\
\end{array}$ & $\begin{array}{l}b \\
b\end{array}$ & $\begin{array}{l}b \\
b\end{array}$ & $\begin{array}{l}\mathrm{b} \\
\mathrm{b}\end{array}$ & $\begin{array}{l}b \\
b\end{array}$ & $\begin{array}{l}w \\
w\end{array}$ & $\begin{array}{l}\mathbf{w} \\
\mathbf{w}\end{array}$ & $\begin{array}{l}w \\
w\end{array}$ & & & & & & & & & & & & & & & A & $\begin{array}{r}4 \\
4 \\
\end{array}$ & $\begin{array}{r}4 \\
4 \\
\end{array}$ & \\
\hline \begin{tabular}{|c|}
$10: 00 \mathrm{am}$ \\
$10: 15 \mathrm{am}$ \\
\end{tabular} & $\begin{array}{l}w \\
w \\
w\end{array}$ & $\begin{array}{l}w \\
w \\
w\end{array}$ & $\begin{array}{l}w \\
w \\
w\end{array}$ & $\begin{array}{l}\mathrm{b} \\
\mathrm{w}\end{array}$ & $\begin{array}{l}b \\
b \\
\end{array}$ & $\begin{array}{l}w \\
w \\
\end{array}$ & $\begin{array}{l}w \\
w\end{array}$ & $\begin{array}{l}w \\
w\end{array}$ & & & & & & & & & & & & & & & $\begin{array}{l}\mathrm{A} \\
\mathrm{A}\end{array}$ & $\begin{array}{l}6 \\
7 \\
\end{array}$ & $\begin{array}{l}6 \\
7 \\
\end{array}$ & \\
\hline $\begin{array}{l}10: 30 \mathrm{am} \\
10: 45 \mathrm{am} \\
\end{array}$ & $\begin{array}{l}w \\
w \\
\end{array}$ & $\begin{array}{l}w \\
w\end{array}$ & $\begin{array}{l}w \\
w\end{array}$ & $\begin{array}{l}w \\
w\end{array}$ & $\begin{array}{l}w \\
w\end{array}$ & $\begin{array}{l}\mathrm{b} \\
\mathrm{b}\end{array}$ & $\begin{array}{l}\mathrm{b} \\
\mathrm{b}\end{array}$ & $\begin{array}{l}w \\
w\end{array}$ & & & & & & & & & & & & & & & A & $\begin{array}{l}6 \\
6 \\
\end{array}$ & $\begin{array}{l}6 \\
6 \\
\end{array}$ & \\
\hline $\begin{array}{l}11: 00 \mathrm{am} \\
11: 15 \mathrm{am} \\
\end{array}$ & $\begin{array}{l}w \\
w \\
w\end{array}$ & $\begin{array}{l}w \\
w\end{array}$ & $\begin{array}{l}w \\
w\end{array}$ & $\begin{array}{l}w \\
w\end{array}$ & $\begin{array}{l}w \\
w\end{array}$ & $\begin{array}{l}b \\
b\end{array}$ & $\begin{array}{l}b \\
b\end{array}$ & $\begin{array}{l}w \\
w\end{array}$ & & & & & & & & & & & & & & & & $\begin{array}{l}6 \\
6 \\
\end{array}$ & $\begin{array}{l}6 \\
6 \\
\end{array}$ & \\
\hline $\begin{array}{l}11: 30 \mathrm{am} \\
11: 45 \mathrm{am} \\
\end{array}$ & $\begin{array}{l}w \\
w \\
w\end{array}$ & $\begin{array}{l}w \\
w\end{array}$ & $\begin{array}{l}w \\
w\end{array}$ & $\begin{array}{l}w \\
w\end{array}$ & $\begin{array}{l}w \\
w \\
\end{array}$ & $\begin{array}{l}w \\
w\end{array}$ & $\begin{array}{l}w \\
w\end{array}$ & $\begin{array}{l}w \\
w\end{array}$ & $\begin{array}{l}w \\
w\end{array}$ & $w$ & $w$ & $w$ & & & & & & & & & & & $\begin{array}{l}A \\
A\end{array}$ & $\begin{array}{c}9 \\
12 \\
\end{array}$ & $\begin{array}{c}9 \\
12 \\
\end{array}$ & \\
\hline $\begin{array}{c}\text { noon } \\
12: 15 \mathrm{pm} \\
\end{array}$ & $\begin{array}{l}w \\
w \\
\end{array}$ & $\begin{array}{l}w \\
w\end{array}$ & $\begin{array}{l}w \\
w\end{array}$ & $\begin{array}{l}w \\
w \\
\end{array}$ & $\begin{array}{l}w \\
w\end{array}$ & $\begin{array}{l}w \\
w\end{array}$ & $\begin{array}{l}w \\
w \\
\end{array}$ & $\begin{array}{l}w \\
w\end{array}$ & $\begin{array}{l}w \\
w \\
w\end{array}$ & $\begin{array}{l}\mathbf{w} \\
\mathbf{w} \\
\end{array}$ & $\begin{array}{l}w \\
w\end{array}$ & $\begin{array}{l}w \\
w \\
\end{array}$ & $\begin{array}{l}w \\
w \\
\end{array}$ & $\begin{array}{l}w \\
w \\
\end{array}$ & $\begin{array}{l}w \\
w\end{array}$ & & & & & & & & $\bar{A}$ & $\begin{array}{l}15 \\
15 \\
\end{array}$ & $\begin{array}{l}15 \\
15 \\
\end{array}$ & \\
\hline $\begin{array}{l}12: 30 \mathrm{pm} \\
12: 45 \mathrm{pm} \\
\end{array}$ & $\bar{w}$ & $w$ & $\begin{array}{l}w \\
w\end{array}$ & $\begin{array}{l}w \\
w \\
\end{array}$ & $\begin{array}{l}w \\
w\end{array}$ & $\begin{array}{l}w \\
w\end{array}$ & $\begin{array}{l}w \\
w\end{array}$ & $w$ & $\begin{array}{l}\mathbf{w} \\
\mathbf{w}\end{array}$ & $\begin{array}{l}w \\
w \\
\end{array}$ & $\begin{array}{l}w \\
w\end{array}$ & $\begin{array}{l}w \\
w \\
\end{array}$ & $\begin{array}{l}w \\
w\end{array}$ & $\begin{array}{l}w \\
w\end{array}$ & $\begin{array}{l}w \\
w \\
\end{array}$ & & & & & & & & A & $\begin{array}{l}15 \\
13 \\
\end{array}$ & $\begin{array}{l}15 \\
13 \\
\end{array}$ & \\
\hline $\begin{array}{l}1: 00 \mathrm{pm} \\
1: 15 \mathrm{pm} \\
\end{array}$ & & & $w$ & $\begin{array}{l}w \\
w \\
\end{array}$ & $\begin{array}{l}w \\
w \\
\end{array}$ & $\begin{array}{l}w \\
w\end{array}$ & $\begin{array}{l}w \\
w \\
\end{array}$ & $\begin{array}{l}\mathrm{b} \\
\mathrm{b}\end{array}$ & $\begin{array}{l}w \\
w\end{array}$ & $\begin{array}{l}w \\
w \\
\end{array}$ & $\begin{array}{l}w \\
w\end{array}$ & $\begin{array}{l}w \\
w \\
\end{array}$ & $\begin{array}{l}\mathbf{w} \\
\mathbf{w}\end{array}$ & $\begin{array}{l}w \\
w \\
\end{array}$ & $\begin{array}{l}w \\
w \\
\end{array}$ & & & & & & & & $\begin{array}{l}\mathrm{A} \\
\mathrm{A}\end{array}$ & $\begin{array}{l}12 \\
11 \\
\end{array}$ & $\begin{array}{l}12 \\
11\end{array}$ & \\
\hline $\begin{array}{l}: 30 \mathrm{pm} \\
1.45 \mathrm{pm} \\
\end{array}$ & & & & & & $\mathbf{w}$ & $\begin{array}{l}w \\
w\end{array}$ & $\begin{array}{l}b \\
b\end{array}$ & $\begin{array}{l}\mathbf{w} \\
\mathrm{b}\end{array}$ & $\begin{array}{l}w \\
w \\
\end{array}$ & $\begin{array}{l}w \\
w\end{array}$ & $\begin{array}{l}w \\
w \\
\end{array}$ & $\begin{array}{l}\mathbf{w} \\
\mathbf{w} \\
\end{array}$ & $\begin{array}{l}w \\
w \\
\end{array}$ & $\begin{array}{l}w \\
w \\
\end{array}$ & & & & & & & & $\begin{array}{l}A \\
A \\
\end{array}$ & $\begin{array}{l}9 \\
7 \\
\end{array}$ & $\begin{array}{l}9 \\
7 \\
\end{array}$ & \\
\hline $\begin{array}{l}2: 00 \mathrm{pm} \\
2: 15 \mathrm{pm} \\
\end{array}$ & & & & & & & $\begin{array}{l}w \\
w\end{array}$ & $\begin{array}{l}w \\
w\end{array}$ & $\begin{array}{l}\mathrm{b} \\
\mathrm{b} \\
\end{array}$ & $\begin{array}{l}b \\
b \\
\end{array}$ & $\begin{array}{l}b \\
b\end{array}$ & $\begin{array}{l}b \\
b \\
\end{array}$ & $\begin{array}{l}w \\
w \\
\end{array}$ & $\begin{array}{l}w \\
w\end{array}$ & $\begin{array}{l}w \\
w\end{array}$ & & & & & & & & A & $\begin{array}{l}5 \\
5 \\
\end{array}$ & $\begin{array}{l}5 \\
5 \\
\end{array}$ & \\
\hline $\begin{array}{l}2: 30 \mathrm{pm} \\
2: 45 \mathrm{pm} \\
\end{array}$ & & & & & & & $\begin{array}{l}w \\
w\end{array}$ & $\begin{array}{l}w \\
w\end{array}$ & $\begin{array}{l}\mathrm{b} \\
\mathrm{w}\end{array}$ & $\begin{array}{l}b \\
b\end{array}$ & $\begin{array}{l}\mathrm{b} \\
\mathrm{b} \\
\end{array}$ & $\begin{array}{l}\mathrm{b} \\
\mathrm{b} \\
\end{array}$ & $\begin{array}{l}w \\
w\end{array}$ & $\begin{array}{l}w \\
w \\
\end{array}$ & $\begin{array}{l}w \\
w \\
\end{array}$ & & & & & & & & A & $\begin{array}{l}5 \\
6 \\
\end{array}$ & $\begin{array}{l}5 \\
6 \\
\end{array}$ & \\
\hline $\begin{array}{l}3: 00 \mathrm{pm} \\
3: 15 \mathrm{pm} \\
\end{array}$ & & & & & & & $\begin{array}{l}w \\
w \\
\end{array}$ & $\begin{array}{l}w \\
w \\
w\end{array}$ & $\begin{array}{l}w \\
w \\
\end{array}$ & $\begin{array}{l}w \\
w \\
w\end{array}$ & $\begin{array}{l}w \\
w\end{array}$ & $\begin{array}{l}w \\
w \\
\end{array}$ & $\begin{array}{l}\mathrm{b} \\
\mathrm{b}\end{array}$ & $\begin{array}{l}b \\
b\end{array}$ & $\begin{array}{l}w \\
w \\
\end{array}$ & & & & & & & & $\bar{A}$ & $\begin{array}{l}7 \\
7 \\
\end{array}$ & $\begin{array}{l}7 \\
7\end{array}$ & \\
\hline \begin{tabular}{|l|}
$3: 30 \mathrm{pm}$ \\
$3: 45 \mathrm{pm}$ \\
\end{tabular} & & & & & & & $w$ & $\begin{array}{l}w \\
w\end{array}$ & $\begin{array}{l}w \\
w\end{array}$ & $\begin{array}{l}\mathbf{w} \\
\mathbf{w}\end{array}$ & $\begin{array}{l}w \\
w\end{array}$ & $\begin{array}{l}w \\
w \\
\end{array}$ & $\begin{array}{l}\mathrm{b} \\
\mathrm{b} \\
\end{array}$ & $\begin{array}{l}\mathrm{b} \\
\mathrm{b}\end{array}$ & $\begin{array}{l}w \\
w\end{array}$ & & & & & & & & A & $\begin{array}{l}7 \\
6 \\
\end{array}$ & $\begin{array}{l}7 \\
6 \\
\end{array}$ & \\
\hline $\begin{array}{l}4: 00 \mathrm{pm} \\
4: 15 \mathrm{pm} \\
\end{array}$ & & & & & & & & & $\begin{array}{l}w \\
w \\
w\end{array}$ & $\begin{array}{l}w \\
w \\
\end{array}$ & $\begin{array}{l}w \\
w\end{array}$ & $\begin{array}{l}w \\
w \\
\end{array}$ & $\begin{array}{l}w \\
w\end{array}$ & $w$ & $\begin{array}{l}\mathrm{b} \\
\mathrm{b}\end{array}$ & & & & & & & & $A$ & $\begin{array}{l}6 \\
6 \\
\end{array}$ & $\begin{array}{l}6 \\
6\end{array}$ & \\
\hline $\begin{array}{r}4: 30 \mathrm{pm} \\
4: 45 \mathrm{pm} \\
\end{array}$ & & & & & & & & & $\begin{array}{l}w \\
w\end{array}$ & $\begin{array}{l}w \\
w\end{array}$ & $\begin{array}{l}w \\
w\end{array}$ & $\begin{array}{l}w \\
w\end{array}$ & $\begin{array}{l}w \\
w \\
\end{array}$ & $\begin{array}{l}w \\
w\end{array}$ & $\begin{array}{l}b \\
b \\
\end{array}$ & $\begin{array}{l}w \\
w \\
\end{array}$ & & & & & & & $\mathrm{~A}$ & $\begin{array}{l}7 \\
7 \\
\end{array}$ & $\begin{array}{l}7 \\
1 \\
\end{array}$ & \\
\hline $\begin{array}{l}\text { 5:00 pm } \\
\text { 5:15 pm } \\
\end{array}$ & & & & & & & & & $\begin{array}{l}w \\
w\end{array}$ & $\begin{array}{l}w \\
w \\
\end{array}$ & $\begin{array}{l}w \\
w \\
\end{array}$ & $\begin{array}{l}\mathbf{w} \\
\mathbf{w}\end{array}$ & $\begin{array}{l}w \\
w \\
\end{array}$ & $\begin{array}{l}w \\
w\end{array}$ & $\begin{array}{l}w \\
w \\
\end{array}$ & $\begin{array}{l}w \\
w \\
\end{array}$ & $w$ & $w$ & & & & & $\begin{array}{l}\mathrm{A} \\
\mathrm{A} \\
\end{array}$ & $\begin{array}{c}8 \\
10 \\
\end{array}$ & $\begin{array}{l}8 \\
10 \\
\end{array}$ & \\
\hline $\begin{array}{l}5: 30 \mathrm{pm} \\
5.45 \mathrm{pm} \\
\end{array}$ & & & & & & & & & $\begin{array}{l}w \\
w\end{array}$ & $\begin{array}{l}w \\
w\end{array}$ & $\begin{array}{l}w \\
w\end{array}$ & $\begin{array}{l}w \\
w\end{array}$ & $\begin{array}{l}w \\
w \\
\end{array}$ & $\begin{array}{l}w \\
w\end{array}$ & $\begin{array}{l}w \\
w\end{array}$ & $\begin{array}{l}w \\
w\end{array}$ & $\begin{array}{l}w \\
w \\
\end{array}$ & $\begin{array}{l}w \\
w\end{array}$ & $\begin{array}{l}w \\
w \\
\end{array}$ & & & & A & $\begin{array}{l}11 \\
12 \\
\end{array}$ & $\begin{array}{l}11 \\
11 \\
\end{array}$ & \\
\hline $\begin{array}{l}6: 00 \mathrm{pm} \\
6: 15 \mathrm{pm}\end{array}$ & & & & & & & & & $\begin{array}{l}\mathbf{w} \\
\mathbf{w}\end{array}$ & $\begin{array}{l}w \\
w \\
w\end{array}$ & $\begin{array}{l}w \\
w\end{array}$ & $\begin{array}{l}w \\
w \\
\end{array}$ & $\begin{array}{l}w \\
w\end{array}$ & $\begin{array}{l}w \\
w\end{array}$ & $\begin{array}{l}w \\
w\end{array}$ & $\begin{array}{l}w \\
w \\
\end{array}$ & $\begin{array}{l}w \\
w\end{array}$ & $\begin{array}{l}w \\
w\end{array}$ & $\begin{array}{l}w \\
w \\
\end{array}$ & $\begin{array}{l}w \\
w \\
w\end{array}$ & & & $\overline{\mathrm{A}}$ & $\begin{array}{ll}12 \\
11 \\
\end{array}$ & $\begin{array}{l}12 \\
12 \\
\end{array}$ & \\
\hline $\begin{array}{l}6: 30 \mathrm{pm} \\
6: 45 \mathrm{pm} \\
\end{array}$ & & & & & & & & & & $\begin{array}{l}w \\
w \\
\end{array}$ & $\begin{array}{l}w \\
w \\
\end{array}$ & $\begin{array}{l}w \\
w\end{array}$ & $\begin{array}{c}w \\
w \\
\end{array}$ & $\begin{array}{l}w \\
w\end{array}$ & $\begin{array}{l}w \\
w \\
\end{array}$ & $\begin{array}{l}\mathrm{b} \\
\mathrm{b} \\
\end{array}$ & $\begin{array}{l}\mathrm{b} \\
\mathrm{b} \\
\end{array}$ & $\begin{array}{l}\mathrm{b} \\
\mathrm{b}\end{array}$ & $\begin{array}{l}w \\
w\end{array}$ & $\begin{array}{l}w \\
w \\
\end{array}$ & $\begin{array}{l}w \\
w\end{array}$ & $\begin{array}{l}w \\
w\end{array}$ & A & $\begin{array}{l}10 \\
10 \\
\end{array}$ & $\begin{array}{l}10 \\
10 \\
\end{array}$ & \\
\hline $\begin{array}{l}7: 00 \mathrm{pm} \\
7: 15 \mathrm{pm} \\
\end{array}$ & & & & & & & & & & & $\begin{array}{l}w \\
w\end{array}$ & $\begin{array}{l}w \\
w\end{array}$ & $\begin{array}{l}w \\
w \\
\end{array}$ & $\begin{array}{l}w \\
w\end{array}$ & $\begin{array}{l}w \\
w \\
\end{array}$ & $\begin{array}{l}b \\
b \\
\end{array}$ & $\begin{array}{l}b \\
b \\
\end{array}$ & $\begin{array}{l}b \\
b \\
\end{array}$ & $\begin{array}{l}w \\
w \\
\end{array}$ & $\begin{array}{l}w \\
w\end{array}$ & $\begin{array}{l}w \\
w\end{array}$ & $\begin{array}{l}w \\
w \\
w\end{array}$ & A & $\begin{array}{l}9 \\
9 \\
9\end{array}$ & $\begin{array}{l}9 \\
9 \\
\end{array}$ & \\
\hline $\begin{array}{l}7: 30 \mathrm{pm} \\
7: 45 \mathrm{pm}\end{array}$ & & & & & & & & & & & $\begin{array}{l}w \\
w\end{array}$ & $\begin{array}{l}w \\
w\end{array}$ & $\begin{array}{l}w \\
w\end{array}$ & $\begin{array}{l}w \\
w\end{array}$ & $\begin{array}{l}w \\
w\end{array}$ & $\begin{array}{l}w \\
w\end{array}$ & $\begin{array}{l}w \\
w\end{array}$ & $\begin{array}{l}w \\
w\end{array}$ & $\begin{array}{l}b \\
b\end{array}$ & $\begin{array}{l}b \\
b\end{array}$ & $\begin{array}{l}\mathrm{b} \\
\mathrm{b}\end{array}$ & $\begin{array}{l}b \\
b\end{array}$ & $\bar{A}$ & $\begin{array}{l}8 \\
8 \\
\end{array}$ & $\begin{array}{l}8 \\
8 \\
\end{array}$ & \\
\hline $\begin{array}{l}8: 00 \mathrm{pm} \\
8: 15 \mathrm{pm} \\
\end{array}$ & & & & & & & & & & & $\begin{array}{l}w \\
w \\
\end{array}$ & $\begin{array}{l}w \\
w \\
\end{array}$ & $\begin{array}{l}w \\
w\end{array}$ & $\begin{array}{l}w \\
w\end{array}$ & $\begin{array}{l}w \\
w \\
\end{array}$ & $\begin{array}{l}w \\
w\end{array}$ & $\begin{array}{l}w \\
w\end{array}$ & $\begin{array}{l}w \\
w\end{array}$ & $\begin{array}{l}b \\
b\end{array}$ & $\begin{array}{l}b \\
b\end{array}$ & $\begin{array}{l}b \\
b \\
\end{array}$ & $\begin{array}{l}\mathrm{b} \\
\mathrm{b}\end{array}$ & & $\begin{array}{l}8 \\
8 \\
\end{array}$ & $\begin{array}{l}8 \\
8 \\
\end{array}$ & \\
\hline $\begin{array}{l}8: 30 \mathrm{pm} \\
8: 45 \mathrm{pm} \\
\end{array}$ & & & & & & & & & & & & & & & & $\begin{array}{l}\mathbf{w} \\
\mathbf{w}\end{array}$ & $\begin{array}{l}w \\
w\end{array}$ & $\begin{array}{l}w \\
w \\
\end{array}$ & $\begin{array}{l}w \\
w\end{array}$ & $\begin{array}{l}w \\
w \\
\end{array}$ & $\begin{array}{l}w \\
w \\
\end{array}$ & $\begin{array}{l}w \\
w \\
\end{array}$ & A & $\begin{array}{l}7 \\
7 \\
\end{array}$ & $\begin{array}{l}7 \\
7 \\
\end{array}$ & \\
\hline $\begin{array}{l}9: 00 \mathrm{pm} \\
9: 15 \mathrm{pm}\end{array}$ & & & & & & & & & & & & & & & & $\begin{array}{l}w \\
w\end{array}$ & $\begin{array}{l}w \\
w \\
\end{array}$ & $\begin{array}{l}w \\
w \\
\end{array}$ & $\begin{array}{l}w \\
w\end{array}$ & $\begin{array}{l}w \\
w\end{array}$ & $\begin{array}{l}w \\
w\end{array}$ & $\begin{array}{c}w \\
w\end{array}$ & & $\begin{array}{l}7 \\
7\end{array}$ & $\begin{array}{l}7 \\
7 \\
\end{array}$ & \\
\hline $\begin{array}{l}9: 30 \mathrm{pm} \\
9: 45 \mathrm{pm}\end{array}$ & & & & & & & & & & & & & & & & $\begin{array}{l}w \\
w\end{array}$ & $\begin{array}{l}w \\
w\end{array}$ & $\begin{array}{l}w \\
w\end{array}$ & $w$ & $\begin{array}{l}w \\
w\end{array}$ & $\begin{array}{l}w \\
w\end{array}$ & $\begin{array}{c}w \\
w\end{array}$ & & $\begin{array}{l}7 \\
7\end{array}$ & $\begin{array}{l}7 \\
7 \\
\end{array}$ & \\
\hline $\begin{array}{l}10.00 \mathrm{pm} \\
10: 15 \mathrm{pm} \\
\end{array}$ & & & & & & & & & & & & & & & & $\begin{array}{l}w \\
w \\
\end{array}$ & \begin{tabular}{|l|}
$w$ \\
$w$ \\
\end{tabular} & \begin{tabular}{|l|}
$w$ \\
$w$ \\
\end{tabular} & $\begin{array}{l}w \\
w \\
\end{array}$ & $\begin{array}{l}w \\
w \\
\end{array}$ & $\begin{array}{l}\mathbf{w} \\
w \\
\end{array}$ & $\begin{array}{c}w \\
w \\
\end{array}$ & & $\begin{array}{l}7 \\
7 \\
\end{array}$ & $\begin{array}{l}7 \\
7 \\
\end{array}$ & \\
\hline $\begin{array}{l}10: 30 \mathrm{pm} \\
10: 45 \mathrm{pm}\end{array}$ & & & & & & & & & & & & & & & & & $\begin{array}{l}w \\
w\end{array}$ & $\begin{array}{l}w \\
w\end{array}$ & $\mathbf{w}$ & $\begin{array}{l}w \\
w\end{array}$ & $\begin{array}{l}w \\
w\end{array}$ & $\begin{array}{c}w \\
w\end{array}$ & $\bar{A}$ & $\begin{array}{l}6 \\
6 \\
\end{array}$ & $\begin{array}{l} \\
6 \\
\end{array}$ & \\
\hline $\begin{array}{l}11: 00 \mathrm{pm} \\
11: 15 \mathrm{pm}\end{array}$ & & & & & & & & & & & & & & & & & $\begin{array}{l}w \\
w\end{array}$ & $\begin{array}{l}w \\
w\end{array}$ & $w$ & $\begin{array}{l}w \\
w\end{array}$ & $\begin{array}{l}w \\
w\end{array}$ & $\begin{array}{c}w \\
w\end{array}$ & & $\begin{array}{l}6 \\
6 \\
\end{array}$ & $\begin{array}{l} \\
6 \\
6\end{array}$ & \\
\hline $\begin{array}{l}11: 30 \mathrm{pm} \\
11: 45 \mathrm{pm}\end{array}$ & & & & & & & & & & & & & & & & & $w$ & $\begin{array}{l}w \\
w \\
\end{array}$ & $\begin{array}{l}w \\
w\end{array}$ & $\begin{array}{l}w \\
w \\
\end{array}$ & $\begin{array}{l}w \\
w\end{array}$ & $\begin{array}{l}w \\
w \\
\end{array}$ & A & $\begin{array}{l}6 \\
5 \\
\end{array}$ & $\begin{array}{l}6 \\
5 \\
\end{array}$ & \\
\hline $\begin{array}{l}\text { midnight } \\
12: 16 \mathrm{am}\end{array}$ & & & & & & & & & & & & & & & & & & $\begin{array}{l}w \\
w\end{array}$ & $w$ & $\begin{array}{l}w \\
w\end{array}$ & $\begin{array}{l}w \\
w\end{array}$ & $\begin{array}{c}w \\
w\end{array}$ & & $\begin{array}{l}5 \\
5\end{array}$ & $\begin{array}{l}5 \\
5\end{array}$ & \\
\hline $\begin{array}{l}12: 30 \mathrm{am} \\
12: 45 \mathrm{am}\end{array}$ & & & & & & & & & & & & & & & & & & $\begin{array}{l}w \\
w\end{array}$ & $w$ & $\begin{array}{l}w \\
w\end{array}$ & $\begin{array}{l}w \\
w\end{array}$ & $\begin{array}{c}w \\
w\end{array}$ & & $\begin{array}{l}5 \\
5\end{array}$ & $\begin{array}{l}5 \\
5 \\
\end{array}$ & \\
\hline $\begin{array}{l}1: 00 \mathrm{am} \\
1: 15 \mathrm{am} \\
\end{array}$ & & & & & & & & & & & & & & & & & & & $\begin{array}{l}w \\
w\end{array}$ & $\begin{array}{l}w \\
w \\
\end{array}$ & $\begin{array}{l}w \\
w\end{array}$ & $\begin{array}{l}w \\
w \\
\end{array}$ & $A$ & $\begin{array}{r}4 \\
4 \\
\end{array}$ & $\begin{array}{l}4 \\
4 \\
\end{array}$ & \\
\hline $\begin{array}{l}1: 30 \mathrm{am} \\
1: 45 \mathrm{am}\end{array}$ & & & & & & & & & & & & & & & & & & & & $w$ & $\begin{array}{l}w \\
w\end{array}$ & $\begin{array}{l}w \\
w\end{array}$ & $\bar{A}$ & $\begin{array}{l}3 \\
3 \\
\end{array}$ & $\begin{array}{r}3 \\
3 \\
\end{array}$ & \\
\hline Total & & & & & & & & & & & & & & & & & & & & & & & 39 & 575 & 576 & \\
\hline
\end{tabular}


Appendix D-Optimal Schedule for the New Model, F3, for the Sample Fast Food Establishment

\begin{tabular}{|c|c|c|c|c|c|c|c|c|c|c|c|c|c|c|c|c|c|c|c|c|c|c|c|c|c|c|c|c|}
\hline Time & & & & & & & & & & & & Empl & loyee & & & & & & & & & & & & & Chara & acteristic & \\
\hline Period & 1 & 2 & 3 & 4 & 5 & 6 & 7 & 8 & 9 & 10 & 11 & 12 & 13 & 14 & 15 & 16 & 12 & \begin{tabular}{|l|}
18 \\
\end{tabular} & 19 & 20 & 21 & 22 & 23 & 124 & \begin{tabular}{|l|}
$A T$ \\
\end{tabular} & $\mathrm{~kg}$ & $W_{k}$ & $\mathrm{Su}$ \\
\hline $\begin{array}{l}6: 00 \mathrm{am} \\
6: 15 \mathrm{am}\end{array}$ & $\begin{array}{l}w \\
w\end{array}$ & $\begin{array}{l}w \\
w\end{array}$ & $\begin{array}{l}\mathbf{w} \\
\mathbf{w}\end{array}$ & $w$ & & & & & & & & & & & & & & & & & & & & & $\begin{array}{l}A \\
A\end{array}$ & $\begin{array}{l}3 \\
4 \\
\end{array}$ & $\begin{array}{l}3 \\
4\end{array}$ & \\
\hline $\begin{array}{l}6.30 \mathrm{am} \\
6.45 \mathrm{am}\end{array}$ & $\begin{array}{l}w \\
w \\
w\end{array}$ & $\begin{array}{l}w \\
w \\
w\end{array}$ & $\begin{array}{l}w \\
w\end{array}$ & $\begin{array}{l}w \\
w\end{array}$ & $\begin{array}{l}w \\
w\end{array}$ & $w$ & & & & & & & & & & & & & & & & & & & $\begin{array}{l}A \\
A\end{array}$ & $\begin{array}{l}5 \\
6 \\
\end{array}$ & $\begin{array}{l}5 \\
6 \\
\end{array}$ & \\
\hline $\begin{array}{l}7: 00 \mathrm{am} \\
7: 15 \mathrm{am}\end{array}$ & $\begin{array}{l}w \\
w \\
\end{array}$ & $\begin{array}{l}\mathbf{w} \\
w \\
\end{array}$ & $\begin{array}{l}w \\
w\end{array}$ & $\begin{array}{l}w \\
w\end{array}$ & $\begin{array}{l}w \\
w\end{array}$ & $\begin{array}{l}w \\
w\end{array}$ & $w$ & & & & & & & & & & & & & & & & & & A & $\begin{array}{l}6 \\
7 \\
\end{array}$ & $\begin{array}{l}6 \\
7 \\
\end{array}$ & \\
\hline $\begin{array}{l}7: 30 \mathrm{am} \\
7: 45 \mathrm{am} \\
\end{array}$ & $\begin{array}{l}w \\
w \\
\end{array}$ & $\begin{array}{l}w \\
w \\
\end{array}$ & $\begin{array}{l}w \\
w \\
w\end{array}$ & $\begin{array}{l}w \\
w\end{array}$ & $\begin{array}{l}w \\
w \\
\end{array}$ & $\begin{array}{l}w \\
w\end{array}$ & $\begin{array}{l}w \\
w\end{array}$ & & & & & & & & & & & & & & & & & & & $\begin{array}{l}7 \\
7 \\
\end{array}$ & $\begin{array}{l}7 \\
7\end{array}$ & \\
\hline $\begin{array}{l}8.00 \mathrm{am} \\
8.15 \mathrm{am} \\
\end{array}$ & $\begin{array}{l}w \\
b\end{array}$ & $w$ & $\begin{array}{l}w \\
w\end{array}$ & $\begin{array}{l}w \\
w\end{array}$ & $\begin{array}{l}w \\
w\end{array}$ & $\begin{array}{l}\mathrm{w} \\
\mathrm{w}\end{array}$ & $\begin{array}{l}w \\
w \\
\end{array}$ & & & & & & & & & & & & & & & & & & $\mathrm{~A}$ & $\begin{array}{l}7 \\
6 \\
\end{array}$ & $\begin{array}{l}7 \\
6 \\
\end{array}$ & \\
\hline $\begin{array}{l}8.30 \mathrm{am} \\
8: 45 \mathrm{am} \\
\end{array}$ & $\begin{array}{l}\mathrm{b} \\
\mathrm{b}\end{array}$ & $\begin{array}{l}w \\
b \\
\end{array}$ & $\begin{array}{l}w \\
w\end{array}$ & $\begin{array}{l}w \\
w \\
\end{array}$ & $\begin{array}{l}w \\
w \\
\end{array}$ & $\begin{array}{l}w \\
w\end{array}$ & $\begin{array}{l}w \\
w \\
\end{array}$ & & & & & & & & & & & & & & & & & & $\mathrm{~A}$ & $\begin{array}{l}6 \\
5 \\
\end{array}$ & $\begin{array}{l}6 \\
5 \\
\end{array}$ & \\
\hline $\begin{array}{l}9: 00 \mathrm{am} \\
9: 15 \mathrm{am} \\
\end{array}$ & $\begin{array}{l}b \\
w \\
\end{array}$ & $\begin{array}{l}\mathrm{b} \\
\mathrm{b} \\
\end{array}$ & $\begin{array}{l}\mathrm{b} \\
\mathrm{b} \\
\end{array}$ & $\begin{array}{l}w \\
b \\
\end{array}$ & $\begin{array}{l}w \\
w \\
\end{array}$ & $\begin{array}{l}w \\
w \\
\end{array}$ & $\begin{array}{l}w \\
w\end{array}$ & $\begin{array}{l}w \\
w \\
\end{array}$ & & & & & & & & & & & & & & & & & \begin{tabular}{l|}
$A$ \\
$A$ \\
\end{tabular} & $\begin{array}{l}5 \\
5 \\
\end{array}$ & $\begin{array}{l}5 \\
5 \\
\end{array}$ & \\
\hline $\begin{array}{l}9: 30 \mathrm{am} \\
\mathrm{g}: 45 \mathrm{am} \\
\end{array}$ & $\begin{array}{l}w \\
w\end{array}$ & $\begin{array}{l}b \\
w\end{array}$ & $\begin{array}{l}b \\
b\end{array}$ & $\begin{array}{l}\mathrm{b} \\
\mathrm{b}\end{array}$ & $\begin{array}{l}b \\
b\end{array}$ & $\begin{array}{l}w \\
w\end{array}$ & $\begin{array}{l}w \\
w\end{array}$ & $\begin{array}{l}\mathbf{w} \\
\mathbf{w}\end{array}$ & & & & & & & & & & & & & & & & & \begin{tabular}{l|}
$A$ \\
$A$ \\
\end{tabular} & $\begin{array}{l}4 \\
4 \\
\end{array}$ & $\begin{array}{l}4 \\
5 \\
\end{array}$ & \\
\hline $\begin{array}{l}10.00 \mathrm{am} \\
10: 15 \mathrm{am} \\
\end{array}$ & $\begin{array}{l}w \\
w\end{array}$ & $\begin{array}{l}w \\
w \\
w\end{array}$ & $\begin{array}{l}w \\
w\end{array}$ & $\begin{array}{l}b \\
w\end{array}$ & \begin{tabular}{|l|}
$b$ \\
$b$ \\
\end{tabular} & $\begin{array}{l}w \\
w\end{array}$ & $\begin{array}{l}w \\
w \\
\end{array}$ & $\begin{array}{l}w \\
w\end{array}$ & & & & & & & & & & & & & & & & & \begin{tabular}{l|}
$A$ \\
$A$
\end{tabular} & $\begin{array}{l}6 \\
7 \\
\end{array}$ & $\begin{array}{l}6 \\
7 \\
\end{array}$ & \\
\hline $\begin{array}{l}10.30 \mathrm{am} \\
10.45 \mathrm{am} \\
\end{array}$ & $\begin{array}{l}w \\
w \\
\end{array}$ & $\begin{array}{l}w \\
w \\
w\end{array}$ & $\begin{array}{l}w \\
w \\
\end{array}$ & $\begin{array}{l}\mathbf{w} \\
\mathbf{w}\end{array}$ & \begin{tabular}{|l}
$w$ \\
$w$ \\
\end{tabular} & $\begin{array}{l}b \\
b \\
\end{array}$ & $\begin{array}{l}\mathrm{b} \\
\mathrm{b} \\
\end{array}$ & $\begin{array}{l}w \\
w\end{array}$ & & & & & & & & & & & & & & & & & A & $\begin{array}{l}6 \\
6 \\
\end{array}$ & $\begin{array}{l}6 \\
6 \\
\end{array}$ & \\
\hline $\begin{array}{l}1100 \mathrm{am} \\
11: 15 \mathrm{am}\end{array}$ & $\begin{array}{l}w \\
w \\
\end{array}$ & $\begin{array}{l}w \\
w \\
w\end{array}$ & $\begin{array}{l}w \\
w\end{array}$ & $\begin{array}{l}\mathbf{w} \\
w\end{array}$ & $\begin{array}{l}w \\
w\end{array}$ & $\begin{array}{l}b \\
b\end{array}$ & $\begin{array}{l}b \\
b\end{array}$ & $\begin{array}{l}w \\
w\end{array}$ & & & & & & & & & & & & & & & & & & $\begin{array}{l}6 \\
6 \\
\end{array}$ & $\begin{array}{l}6 \\
6 \\
\end{array}$ & \\
\hline $\begin{array}{l}11: 30 \mathrm{am} \\
11: 45 \mathrm{am}\end{array}$ & $\begin{array}{l}w \\
w\end{array}$ & $\begin{array}{c}w \\
w\end{array}$ & $\begin{array}{l}w \\
w\end{array}$ & $\begin{array}{l}w \\
w\end{array}$ & $\begin{array}{l}w \\
w\end{array}$ & $\begin{array}{l}w \\
w\end{array}$ & $\begin{array}{l}w \\
w\end{array}$ & $\begin{array}{l}w \\
w\end{array}$ & $\begin{array}{l}w \\
w\end{array}$ & w & $w$ & $w$ & & & & & & & & & & & & & \begin{tabular}{|l|l}
$A$ & \\
\end{tabular} & $\begin{array}{c}9 \\
12 \\
\end{array}$ & $\begin{array}{c}9 \\
12\end{array}$ & \\
\hline $\begin{array}{c}\text { noon } \\
12: 15 \mathrm{pm}\end{array}$ & $\begin{array}{l}w \\
w\end{array}$ & $\begin{array}{c}w \\
w \\
w\end{array}$ & $\begin{array}{l}w \\
w\end{array}$ & $\begin{array}{l}w \\
w\end{array}$ & $\begin{array}{l}w \\
w\end{array}$ & $\begin{array}{l}w \\
w\end{array}$ & $\begin{array}{l}w \\
w \\
w\end{array}$ & $\begin{array}{l}w \\
w\end{array}$ & $\begin{array}{l}w \\
w\end{array}$ & $\begin{array}{l}w \\
w\end{array}$ & $\begin{array}{l}w \\
w \\
w\end{array}$ & $\begin{array}{l}w \\
w \\
\end{array}$ & $\begin{array}{l}w \\
w\end{array}$ & $\begin{array}{l}w \\
w\end{array}$ & \begin{tabular}{|l|}
$w$ \\
$w$
\end{tabular} & & & & & & & & & & A & $\begin{array}{l}15 \\
15 \\
\end{array}$ & $\begin{array}{l}15 \\
15\end{array}$ & \\
\hline $\begin{array}{l}12: 30 \mathrm{pm} \\
12: 45 \mathrm{pm} \\
\end{array}$ & w & $w$ & $\begin{array}{l}w \\
w \\
\end{array}$ & $\begin{array}{l}w \\
w \\
\end{array}$ & \begin{tabular}{|l}
$w$ \\
$w$ \\
\end{tabular} & $\begin{array}{l}w \\
w \\
\end{array}$ & $\begin{array}{l}w \\
w \\
\end{array}$ & $\begin{array}{l}w \\
w\end{array}$ & $\begin{array}{l}w \\
w \\
w\end{array}$ & \begin{tabular}{|l}
$\mathbf{w}$ \\
$\mathbf{w}$ \\
\end{tabular} & $\begin{array}{l}w \\
w \\
\end{array}$ & \begin{tabular}{|l|}
$w$ \\
$w$ \\
\end{tabular} & \begin{tabular}{|l|}
$w$ \\
$w$ \\
\end{tabular} & \begin{tabular}{|c|}
$w$ \\
$w$ \\
\end{tabular} & \begin{tabular}{|c|}
$w$ \\
$w$ \\
\end{tabular} & & & & & & & & & & $A$ & $\begin{array}{l}15 \\
13 \\
\end{array}$ & $\begin{array}{r}15 \\
13 \\
\end{array}$ & \\
\hline $\begin{array}{l}1: 00 \mathrm{pm} \\
1: 15 \mathrm{pm}\end{array}$ & & & & $\begin{array}{l}w \\
w \\
\end{array}$ & $\begin{array}{l}w \\
w\end{array}$ & $\begin{array}{l}w \\
w\end{array}$ & $\begin{array}{l}w \\
w \\
\end{array}$ & $\begin{array}{l}w \\
b\end{array}$ & $\begin{array}{l}w \\
w \\
\end{array}$ & $\begin{array}{l}w \\
w \\
\end{array}$ & $\begin{array}{l}w \\
w \\
\end{array}$ & \begin{tabular}{|c|}
$w$ \\
$w$ \\
\end{tabular} & \begin{tabular}{|c|}
$w$ \\
$w$ \\
\end{tabular} & \begin{tabular}{|c|}
$w$ \\
$w$ \\
\end{tabular} & \begin{tabular}{|c|}
$w$ \\
$w$ \\
\end{tabular} & & & & & & & & & & \begin{tabular}{|l|}
$A$ \\
$A$ \\
\end{tabular} & $\begin{array}{l}12 \\
11 \\
\end{array}$ & $\begin{array}{l}12 \\
11 \\
\end{array}$ & \\
\hline $\begin{array}{l}1: 30 \mathrm{pm} \\
1: 45 \mathrm{pm} \\
\end{array}$ & & & & & & $w$ & $\begin{array}{l}w \\
w\end{array}$ & $\begin{array}{l}b \\
b \\
\end{array}$ & \begin{tabular}{|l}
$w$ \\
$b$ \\
\end{tabular} & $\begin{array}{l}w \\
w\end{array}$ & $\begin{array}{l}w \\
w\end{array}$ & \begin{tabular}{|l|}
$w$ \\
$w$ \\
\end{tabular} & $\begin{array}{l}w \\
w \\
\end{array}$ & \begin{tabular}{|c|}
$w$ \\
$w$ \\
\end{tabular} & \begin{tabular}{|l|}
$w$ \\
$w$ \\
\end{tabular} & & & & & & & & & & $\begin{array}{l}A \\
A \\
\end{array}$ & $\begin{array}{l}9 \\
7 \\
\end{array}$ & $\begin{array}{l}9 \\
7 \\
\end{array}$ & \\
\hline $\begin{array}{l}2.00 \mathrm{pm} \\
2: 15 \mathrm{pm} \\
\end{array}$ & & & & & & & & $\begin{array}{l}\mathrm{b} \\
\mathrm{w}\end{array}$ & $\begin{array}{l}\mathrm{b} \\
\mathrm{b} \\
\end{array}$ & $\begin{array}{l}b \\
b \\
\end{array}$ & \begin{tabular}{|l|}
$w$ \\
$b$ \\
\end{tabular} & \begin{tabular}{|l|}
$w$ \\
$w$ \\
\end{tabular} & \begin{tabular}{|l|}
$w$ \\
$w$ \\
\end{tabular} & \begin{tabular}{|c|}
$\mathbf{w}$ \\
$\mathbf{w}$ \\
\end{tabular} & \begin{tabular}{|l|}
$w$ \\
$w$ \\
\end{tabular} & & & & & & & & & & $\begin{array}{l}\mathrm{A} \\
\mathrm{A}\end{array}$ & $\begin{array}{l}5 \\
5 \\
\end{array}$ & $\begin{array}{l}5 \\
5 \\
\end{array}$ & \\
\hline $\begin{array}{l}2: 30 \mathrm{pm} \\
2: 45 \mathrm{pm}\end{array}$ & & & & & & & & $\begin{array}{l}w \\
w\end{array}$ & $\begin{array}{l}b \\
w\end{array}$ & $\begin{array}{l}\mathrm{b} \\
\mathrm{b}\end{array}$ & $\begin{array}{l}b \\
b \\
\end{array}$ & \begin{tabular}{|l|}
$w$ \\
$w$ \\
\end{tabular} & $\begin{array}{l}w \\
w \\
\end{array}$ & \begin{tabular}{|l|}
$\mathbf{w}$ \\
$\mathbf{w}$ \\
\end{tabular} & \begin{tabular}{|l|}
$w$ \\
$w$ \\
\end{tabular} & & & & & & & & & & A & $\begin{array}{l}5 \\
6 \\
\end{array}$ & $\begin{array}{l}5 \\
6 \\
\end{array}$ & \\
\hline $\begin{array}{l}3.00 \mathrm{pm} \\
3: 15 \mathrm{pm} \\
\end{array}$ & & & & & & & & $\begin{array}{l}w \\
w\end{array}$ & $\begin{array}{l}w \\
w \\
\end{array}$ & $\begin{array}{l}w \\
w \\
\end{array}$ & $\begin{array}{l}b \\
w\end{array}$ & \begin{tabular}{|c|}
$w$ \\
$b$ \\
\end{tabular} & \begin{tabular}{|c|}
$w$ \\
$w$ \\
\end{tabular} & \begin{tabular}{|l|}
$w$ \\
$w$ \\
\end{tabular} & \begin{tabular}{|l|}
$w$ \\
$w$ \\
\end{tabular} & & & & & & & & & & \begin{tabular}{|l|l}
$\mathrm{A}$ \\
$\mathrm{A}$
\end{tabular} & $\begin{array}{l}7 \\
7 \\
\end{array}$ & $\begin{array}{l}7 \\
1 \\
\end{array}$ & \\
\hline $\begin{array}{l}3.30 \mathrm{pm} \\
3.45 \mathrm{pm} \\
\end{array}$ & & & & & & & & $w$ & $\begin{array}{l}w \\
w \\
\end{array}$ & $\begin{array}{l}w \\
w \\
\end{array}$ & $\begin{array}{l}w \\
w \\
w\end{array}$ & \begin{tabular}{|l|}
$b$ \\
$b$ \\
\end{tabular} & \begin{tabular}{|l|}
$w$ \\
$w$ \\
\end{tabular} & \begin{tabular}{|l|}
$w$ \\
$w$ \\
\end{tabular} & $\begin{array}{l}w \\
w \\
\end{array}$ & & & & & & & & & & A & $\begin{array}{l}7 \\
6 \\
\end{array}$ & $\begin{array}{l}7 \\
6 \\
\end{array}$ & \\
\hline $\begin{array}{l}4: 00 \mathrm{pm} \\
4: 15 \mathrm{pm} \\
\end{array}$ & & & & & & & & & $\begin{array}{l}w \\
w \\
\end{array}$ & $\begin{array}{l}w \\
w\end{array}$ & $\begin{array}{l}w \\
w \\
w\end{array}$ & \begin{tabular}{|c|}
$b$ \\
$w$ \\
\end{tabular} & \begin{tabular}{|l|}
$b$ \\
$b$ \\
\end{tabular} & $\begin{array}{l}\mathrm{w} \\
\mathrm{b} \\
\end{array}$ & $\begin{array}{l}w \\
w \\
\end{array}$ & $\begin{array}{l}w \\
w\end{array}$ & & & & & & & & & \begin{tabular}{|l|l|}
$A$ \\
$A$ \\
\end{tabular} & $\begin{array}{l}6 \\
6 \\
\end{array}$ & $\begin{array}{l}6 \\
6 \\
\end{array}$ & \\
\hline $\begin{array}{l}4: 30 \mathrm{pm} \\
4: 45 \mathrm{pm} \\
\end{array}$ & & & & & & & & & $\begin{array}{l}w \\
w \\
\end{array}$ & $\begin{array}{l}w \\
w\end{array}$ & $\begin{array}{l}w \\
w\end{array}$ & \begin{tabular}{|l|}
$w$ \\
$w$ \\
\end{tabular} & $\begin{array}{l}b \\
b \\
\end{array}$ & \begin{tabular}{|l|}
$b$ \\
$b$ \\
\end{tabular} & $\begin{array}{l}w \\
b \\
\end{array}$ & \begin{tabular}{|l}
$w$ \\
$w$ \\
\end{tabular} & \begin{tabular}{l|}
$w$ \\
$w$
\end{tabular} & $w$ & & & & & & & $\begin{array}{l}A \\
A\end{array}$ & $\begin{array}{l}7 \\
1 \\
\end{array}$ & $\begin{array}{l} \\
? \\
\end{array}$ & \\
\hline $\begin{array}{l}5: 00 \mathrm{pm} \\
5: 15 \mathrm{pm}\end{array}$ & & & & & & & & & $\begin{array}{l}w \\
w \\
\end{array}$ & $\begin{array}{l}w \\
w \\
\end{array}$ & $\begin{array}{l}w \\
w\end{array}$ & \begin{tabular}{|l|}
$w$ \\
$w$ \\
\end{tabular} & \begin{tabular}{|c|}
$w$ \\
$w$ \\
\end{tabular} & $\begin{array}{l}b \\
w \\
\end{array}$ & $\begin{array}{l}b \\
b \\
\end{array}$ & $\begin{array}{l}\mathrm{w} \\
\mathrm{w}\end{array}$ & \begin{tabular}{|l|}
$w$ \\
$w$ \\
\end{tabular} & $\begin{array}{l}w \\
w \\
\end{array}$ & $\mathrm{w}$ & & & & & & $\begin{array}{l}\mathrm{A} \\
\mathrm{A}\end{array}$ & $\begin{array}{c}8 \\
10 \\
\end{array}$ & $\begin{array}{c}8 \\
10 \\
\end{array}$ & \\
\hline $\begin{array}{l}5: 30 \mathrm{pm} \\
5: 45 \mathrm{pm} \\
\end{array}$ & & & & & & & & & $\begin{array}{l}w \\
w\end{array}$ & $\begin{array}{l}w \\
w\end{array}$ & $\begin{array}{l}w \\
w\end{array}$ & \begin{tabular}{|l|}
$\mathbf{w}$ \\
$\mathbf{w}$ \\
\end{tabular} & $\begin{array}{l}w \\
w \\
\end{array}$ & \begin{tabular}{|l|}
$w$ \\
$w$ \\
\end{tabular} & $\begin{array}{l}b \\
w\end{array}$ & $\begin{array}{l}w \\
w\end{array}$ & $\begin{array}{l}\mathrm{w} \\
\mathrm{w}\end{array}$ & \begin{tabular}{|l|}
$w$ \\
$w$ \\
\end{tabular} & \begin{tabular}{|l|}
$w$ \\
$w$ \\
\end{tabular} & $\begin{array}{l}w \\
w \\
\end{array}$ & & & & & $\begin{array}{l}A \\
A\end{array}$ & $\begin{array}{l}11 \\
12 \\
\end{array}$ & $\begin{array}{l}11 \\
12 \\
\end{array}$ & \\
\hline $\begin{array}{l}6: 00 \mathrm{pm} \\
6: 15 \mathrm{pm} \\
\end{array}$ & & & & & & & & & $\begin{array}{l}w \\
w \\
w\end{array}$ & \begin{tabular}{|l|}
$\mathbf{w}$ \\
$\mathbf{w}$ \\
\end{tabular} & $\begin{array}{l}w \\
w\end{array}$ & $\begin{array}{l}w \\
w \\
\end{array}$ & \begin{tabular}{|l}
$w$ \\
$w$ \\
\end{tabular} & $\begin{array}{l}w \\
w \\
\end{array}$ & $\begin{array}{l}w \\
w \\
\end{array}$ & \begin{tabular}{|l|}
$b$ \\
$b$ \\
\end{tabular} & $\begin{array}{c}\mathrm{w} \\
\mathrm{b} \\
\end{array}$ & \begin{tabular}{|c|}
$w$ \\
$w$ \\
\end{tabular} & \begin{tabular}{|l|}
$w$ \\
$w$
\end{tabular} & $\begin{array}{l}w \\
w \\
\end{array}$ & $\begin{array}{l}w \\
w \\
w\end{array}$ & & & & $\begin{array}{l}\mathrm{A} \\
\mathrm{A}\end{array}$ & $\begin{array}{l}12 \\
11 \\
\end{array}$ & $\begin{array}{l}12 \\
11 \\
\end{array}$ & \\
\hline $\begin{array}{l}6: 30 \mathrm{pm} \\
6: 45 \mathrm{pm} \\
\end{array}$ & & & & & & & & & & \begin{tabular}{|l|}
$w$ \\
$w$ \\
\end{tabular} & $\begin{array}{l}w \\
w\end{array}$ & \begin{tabular}{|l|}
$w$ \\
$w$ \\
\end{tabular} & $\begin{array}{l}w \\
w \\
\end{array}$ & $\begin{array}{l}w \\
w \\
\end{array}$ & $\begin{array}{l}w \\
w \\
\end{array}$ & \begin{tabular}{|l|}
$b$ \\
$b$ \\
\end{tabular} & $\begin{array}{l}b \\
b \\
\end{array}$ & \begin{tabular}{|l|}
$w$ \\
$w$ \\
\end{tabular} & \begin{tabular}{|l|}
$w$ \\
$w$
\end{tabular} & $\begin{array}{l}w \\
w \\
\end{array}$ & $\begin{array}{l}w \\
w \\
\end{array}$ & & & & $A$ & $\begin{array}{l}10 \\
10 \\
\end{array}$ & $\begin{array}{l}10 \\
10 \\
\end{array}$ & \\
\hline $\begin{array}{l}7: 00 \mathrm{pm} \\
7.15 \mathrm{pm} \\
\end{array}$ & & & & & & & & & & & & \begin{tabular}{|l|}
$w$ \\
$w$ \\
\end{tabular} & \begin{tabular}{|l|}
$w$ \\
$w$ \\
\end{tabular} & $\begin{array}{l}w \\
w\end{array}$ & \begin{tabular}{|l|}
$w$ \\
$w$ \\
\end{tabular} & \begin{tabular}{|c|}
$w$ \\
$w$ \\
\end{tabular} & $\begin{array}{l}b \\
w\end{array}$ & \begin{tabular}{|c|}
$w$ \\
$b$ \\
\end{tabular} & \begin{tabular}{|c|}
$w$ \\
$w$ \\
\end{tabular} & $\begin{array}{l}w \\
w\end{array}$ & $\begin{array}{l}w \\
w \\
\end{array}$ & & & & $\begin{array}{l}A \\
A\end{array}$ & $\begin{array}{l}9 \\
9 \\
\end{array}$ & $\begin{array}{l}9 \\
9 \\
\end{array}$ & \\
\hline $\begin{array}{l}7: 30 \mathrm{pm} \\
7.45 \mathrm{pm} \\
\end{array}$ & & & & & & & & & & & & & $w$ & $\begin{array}{l}w \\
w \\
\end{array}$ & $\begin{array}{l}w \\
w\end{array}$ & $\begin{array}{l}w \\
w \\
\end{array}$ & $\begin{array}{l}\mathbf{w} \\
w\end{array}$ & $\begin{array}{l}b \\
b\end{array}$ & \begin{tabular}{|c|}
$w$ \\
$b$ \\
\end{tabular} & $\begin{array}{l}w \\
w \\
\end{array}$ & $\begin{array}{l}w \\
w \\
w\end{array}$ & $w$ & $w$ & & $\begin{array}{l}A \\
A\end{array}$ & $\begin{array}{l}8 \\
8 \\
\end{array}$ & $\begin{array}{l}8 \\
8 \\
\end{array}$ & \\
\hline $\begin{array}{l}8: 00 \mathrm{pm} \\
8: 15 \mathrm{pm}\end{array}$ & & & & & & & & & & & & & & $w$ & \begin{tabular}{|l|}
$w$ \\
$w$ \\
\end{tabular} & \begin{tabular}{|l|}
$w$ \\
$w$ \\
\end{tabular} & $\begin{array}{l}w \\
w \\
\end{array}$ & $\begin{array}{l}b \\
w \\
\end{array}$ & $\begin{array}{l}b \\
b \\
\end{array}$ & $\begin{array}{l}\mathrm{b} \\
\mathrm{b} \\
\end{array}$ & $\begin{array}{l}\mathbf{w} \\
w \\
w\end{array}$ & $\begin{array}{l}w \\
w \\
\end{array}$ & \begin{tabular}{|l|}
$w$ \\
$w$
\end{tabular} & $\begin{array}{l}w \\
w \\
\end{array}$ & A & $\begin{array}{l}8 \\
8 \\
\end{array}$ & $\begin{array}{l}8 \\
8 \\
\end{array}$ & \\
\hline $\begin{array}{l}8: 30 \mathrm{pm} \\
8: 45 \mathrm{pm} \\
\end{array}$ & & & & & & & & & & & & & & & $\begin{array}{l}w \\
w \\
\end{array}$ & \begin{tabular}{|l|}
$w$ \\
$w$ \\
\end{tabular} & $\begin{array}{l}w \\
w \\
\end{array}$ & \begin{tabular}{l|}
$w$ \\
$w$ \\
\end{tabular} & \begin{tabular}{|c|}
$b$ \\
$w$ \\
\end{tabular} & $\begin{array}{l}b \\
b \\
\end{array}$ & $\begin{array}{l}b \\
b\end{array}$ & $\begin{array}{l}w \\
b \\
\end{array}$ & \begin{tabular}{|l|}
$w$ \\
$w$ \\
\end{tabular} & $\begin{array}{l}w \\
w \\
\end{array}$ & \begin{tabular}{|l|l|}
$A$ \\
$A$
\end{tabular} & $\begin{array}{l}7 \\
7 \\
\end{array}$ & $\begin{array}{l}7 \\
7 \\
\end{array}$ & \\
\hline $\begin{array}{l}9: 00 \mathrm{pm} \\
9: 15 \mathrm{pm} \\
\end{array}$ & & & & & & & & & & & & & & & $\begin{array}{l}w \\
w \\
\end{array}$ & \begin{tabular}{|l|}
$w$ \\
$w$
\end{tabular} & $\begin{array}{l}w \\
w \\
\end{array}$ & \begin{tabular}{|l|}
$\mathbf{w}$ \\
$\mathbf{w}$ \\
\end{tabular} & \begin{tabular}{|l|}
$w$ \\
$w$ \\
\end{tabular} & $\begin{array}{l}w \\
w \\
\end{array}$ & $\begin{array}{l}b \\
b\end{array}$ & $\begin{array}{l}b \\
b \\
\end{array}$ & $\begin{array}{l}b \\
b\end{array}$ & $\begin{array}{l}w \\
w\end{array}$ & A & $\begin{array}{l}7 \\
7 \\
\end{array}$ & $\begin{array}{l}7 \\
7 \\
\end{array}$ & \\
\hline $\begin{array}{l}9: 30 \mathrm{pm} \\
9: 45 \mathrm{pm}\end{array}$ & & & & & & & & & & & & & & & & \begin{tabular}{|l|}
$w$ \\
$w$ \\
\end{tabular} & $\begin{array}{l}w \\
w \\
\end{array}$ & \begin{tabular}{|l|}
$w$ \\
$w$ \\
\end{tabular} & $\begin{array}{l}w \\
w\end{array}$ & $\begin{array}{l}w \\
w \\
w\end{array}$ & \begin{tabular}{|c|} 
\\
$w$
\end{tabular} & $\begin{array}{l}\mathrm{b} \\
w\end{array}$ & $\begin{array}{l}b \\
b\end{array}$ & $\begin{array}{l}w \\
b \\
\end{array}$ & $\begin{array}{l}A \\
A\end{array}$ & $\begin{array}{l}7 \\
7 \\
\end{array}$ & $\begin{array}{l}7 \\
7 \\
\end{array}$ & \\
\hline $\begin{array}{l}10: 00 \mathrm{pm} \\
10: 15 \mathrm{pm}\end{array}$ & & & & & & & & & & & & & & & & & $\begin{array}{l}w \\
w \\
\end{array}$ & \begin{tabular}{|l|}
$w$ \\
$w$ \\
\end{tabular} & \begin{tabular}{|l|}
$w$ \\
$w$ \\
\end{tabular} & $\begin{array}{l}w \\
w \\
\end{array}$ & $\begin{array}{l}w \\
w \\
\end{array}$ & $\begin{array}{l}w \\
w \\
\end{array}$ & \begin{tabular}{|c|}
$w$ \\
$w$ \\
\end{tabular} & $\begin{array}{l}b \\
b \\
\end{array}$ & $\bar{A}$ & $\begin{array}{l}7 \\
1 \\
\end{array}$ & $\begin{array}{l}7 \\
I \\
\end{array}$ & \\
\hline $\begin{array}{l}10: 30 \mathrm{pm} \\
10: 45 \mathrm{pm}\end{array}$ & & & & & & & & & & & & & & & & & & $w$ & \begin{tabular}{|c|}
$w$ \\
$w$ \\
\end{tabular} & $\begin{array}{l}w \\
w \\
\end{array}$ & $\begin{array}{l}w \\
w \\
\end{array}$ & $\begin{array}{l}w \\
w\end{array}$ & \begin{tabular}{|l|}
$w$ \\
$w$ \\
\end{tabular} & $\begin{array}{l}b \\
w\end{array}$ & \begin{tabular}{|l|}
$A$ \\
$A$
\end{tabular} & $\begin{array}{l}6 \\
6 \\
\end{array}$ & $\begin{array}{l}6 \\
6 \\
\end{array}$ & \\
\hline $\begin{array}{l}11: 00 \mathrm{pm} \\
11: 15 \mathrm{pm}\end{array}$ & & & & & & & & & & & & & & & & & & & $\begin{array}{l}w \\
w\end{array}$ & $\begin{array}{l}w \\
w\end{array}$ & $\begin{array}{l}\mathbf{w} \\
\mathbf{w}\end{array}$ & $\begin{array}{l}w \\
w\end{array}$ & \begin{tabular}{|l}
$w$ \\
$w$
\end{tabular} & $\begin{array}{l}\mathbf{w} \\
w\end{array}$ & & $\begin{array}{l}6 \\
6 \\
\end{array}$ & $\begin{array}{l}6 \\
6\end{array}$ & \\
\hline $\begin{array}{l}11: 30 \mathrm{pm} \\
11.45 \mathrm{pm}\end{array}$ & & & & & & & & & & & & & & & & & & & $w$ & $\begin{array}{l}w \\
w \\
\end{array}$ & \begin{tabular}{|c|}
$w$ \\
$w$ \\
\end{tabular} & $\begin{array}{l}w \\
w \\
\end{array}$ & $\begin{array}{l} \\
w \\
\end{array}$ & $\begin{array}{l}\mathbf{w} \\
\mathbf{w} \\
\end{array}$ & A & $\begin{array}{l}6 \\
5 \\
\end{array}$ & $\begin{array}{l}6 \\
5 \\
\end{array}$ & \\
\hline $\begin{array}{l}\text { midnight } \\
12: 15 \mathrm{am}\end{array}$ & & & & & & & & & & & & & & & & & & & & $\begin{array}{l}w \\
w \\
\end{array}$ & \begin{tabular}{|l|}
$w$ \\
$w$ \\
\end{tabular} & $\begin{array}{l}w \\
w \\
\end{array}$ & \begin{tabular}{|l|}
$w$ \\
$w$ \\
\end{tabular} & $\begin{array}{l}w \\
w \\
\end{array}$ & & $\begin{array}{l}5 \\
5 \\
\end{array}$ & $\begin{array}{l}5 \\
5 \\
\end{array}$ & \\
\hline $\begin{array}{l}12: 30 \mathrm{am} \\
12: 45 \mathrm{am} \\
\end{array}$ & & & & & & & & & & & & & & & & & & & & $\begin{array}{l}w \\
w \\
\end{array}$ & $\begin{array}{l}w \\
w\end{array}$ & $\begin{array}{l}w \\
w\end{array}$ & $\begin{array}{l}w \\
w\end{array}$ & $\begin{array}{l}w \\
w\end{array}$ & & $\begin{array}{l}5 \\
5 \\
\end{array}$ & $\begin{array}{l}5 \\
5 \\
\end{array}$ & \\
\hline $\begin{array}{l}1.00 \mathrm{am} \\
1.15 \mathrm{am} \\
\end{array}$ & & & & & & & & & & & & & & & & & & & & & \begin{tabular}{|l|}
$w$ \\
$w$ \\
\end{tabular} & $\begin{array}{l}w \\
w \\
\end{array}$ & \begin{tabular}{|l|}
$w$ \\
$w$ \\
\end{tabular} & $\begin{array}{l}w \\
w \\
\end{array}$ & $\bar{A}$ & $\begin{array}{l}4 \\
4 \\
\end{array}$ & $\begin{array}{l}4 \\
4 \\
\end{array}$ & \\
\hline $\begin{array}{l}1: 30 \mathrm{am} \\
1: 45 \mathrm{am}\end{array}$ & & & & & & & & & & & & & & & & & & & & & & $\begin{array}{l}w \\
w \\
\end{array}$ & \begin{tabular}{|l|}
$w$ \\
$w$ \\
\end{tabular} & $\begin{array}{l}w \\
w \\
\end{array}$ & $\begin{array}{ll}\mathrm{A} \\
\end{array}$ & $\begin{array}{l}3 \\
3 \\
\end{array}$ & $\begin{array}{l}3 \\
3 \\
\end{array}$ & \\
\hline Total & & & & & & & & & & & & & & & & & & & & & & & & & \begin{tabular}{|l|l|}
56 \\
\end{tabular} & \begin{tabular}{|l|l|}
575 \\
\end{tabular} & \begin{tabular}{|l|l|}
576 \\
\end{tabular} & \\
\hline
\end{tabular}

$\mathrm{W}=\mathrm{a}$ work period; $\mathrm{B}=\mathrm{a}$ break period; $\mathrm{AT}=\mathrm{A}$ if an action occurs at the start of the period; $\mathrm{Rq}=$ number of employees required; $\mathrm{Wk}=$ number of enployees scheduled; Su number of surplus employees 